\title{
The Prophet as a Sacred Spring: Late Ottoman Hilye Bottles
}

\author{
Christiane Gruber
}

Among its vast collection of manuscripts, the Topkapı Palace Library in Istanbul preserves four large glass bottles filled with devotional objects and ornaments. Three of these bottles contain hilyes, or verbal descriptions of the Prophet Muhammad, while a fourth contains a miniature Qurān displayed on a wooden stand decorated with colorful beads (Figure 18.1). Executed by the under-glass painter Muhammad Rif'at and dated 1308/1891, the Qurān bottle has at least four companion pieces held in two other museums in Istanbul. ${ }^{1}$ Although Qurān bottles will not be discussed in the present essay, their production alongside hilye bottles suggests that these glass containers were intended to house both the icons of God (via His holy book) and the Prophet (via his verbal icon).

At present, hilye bottles remain understudied. While about a dozen exist in international collections, ${ }^{2}$ one bottle emerged on the art market some years ago under the title "lodge hilye" (tekke hilyesi) ${ }^{3}$ and another hilye bottle dated 1219/1804-5 is currently on display in the Mevlevihane Museum in Galata, Istanbul. ${ }^{4}$ As is evident from the Topkapı Palace materials, however, hilye

1 Two bottles are held in the Sadberk Hanım Museum, nos. 18257 and 18258 (cat. nos. 218-219). Like the Topkapı Qurān bottle, these two items are signed by Muhammad Rif'at and dated 1308/1891; however, neither contains any objects, which may have been lost or removed. Two other inscribed bottles are published in Şentürk, Cam altında yirmi bin fersah, 20, 112. The bottle on page 2o, now held in the Museum of Turkish Calligraphic Art (Türk Vakıflar Hat Sanatları Müzesi) in Istanbul, is especially noteworthy as it, too, contains a miniature Quraan displayed on a stand.

2 Among others, see the four hilye bottles held in the Turkish and Islamic Arts Museum in Istanbul, published in Türk ve İslâm Eserleri Müzesi Rehberi, 36-37, nos. 1072-1075.

3 See the nineteenth-century hilye bottle offered for sale in Alif Art, 26, available online at: http://www.lebrizimages.com/img/glrs/o369/web/muzo8o9/html/muzo8og.html\#26/z (accessed in 2018; website no longer active). Moreover, a rosewater bottle, filled with decorative elements and dated $1321 / 1903^{-4}$, also displays similarities to hilye icons and suggests the water's use in Sufi rituals; see Işın and Özpalabıyıklar, "Hoş gör yâ hû", 142-143.

4 See the hilye bottle on display in the Galata Mevlevihane Müzesi, Istanbul, acc. no. 299, dated $1219 / 1804-5$.

(C) CHRISTIANE GRUBER, 2022 | DOI:10.1163/9789004466739_021

This is an open access chapter distributed under the terms of the CC BY-NC-ND Aro license. Gruber - 9789004466739 


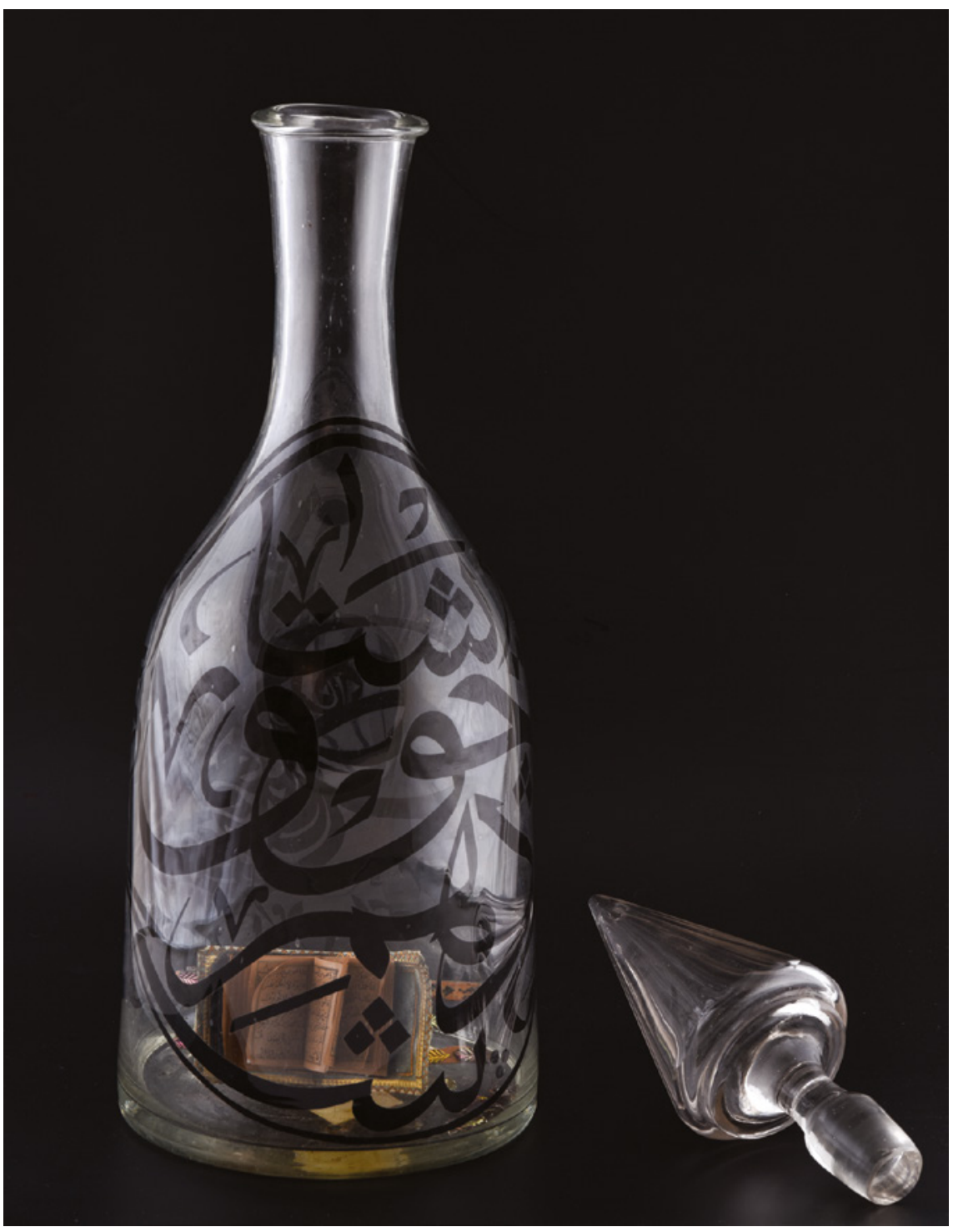

FIGURE 18.1 Inscribed glass bottle containing a miniature Qurān placed on a stand and surrounded by decorative beads, Ottoman lands, late 19th century. Topkapı Palace Museum Library, Istanbul, G.Y. 913

bottles should not be restricted to Sufi lodges alone. Rather, these relatively rare objects appear to have been used for both talismanic and curative purposes in various contexts and milieus, including royal ones.

Although the origins of late Ottoman-Islamic icon-bottles remain open to speculation, these objects recall Byzantine and post-Byzantine Christian 
artworks and ceremonies linked to Constantinople's holy springs, or hagiasmata. Such springs, known in Turkish as ayazmas, have served as sacred sites to Muslims over the centuries as well. Still today, Istanbul's ayazmas are filled with decorated icons and bottles containing images of the Virgin Mary - herself considered a sacred source of life - and Jesus Christ. These icons, bottles, and their sacred spring water were, and still are, believed to intercede on believers' behalf and to secure miraculous cures.

Such Christian traditions appear to have been adopted and adapted within Ottoman spheres, where other types of bottles meant to contain holy liquid among them Zamzam water bottles and magico-medicinal vessels - merged to create a larger corpus of Islamic devotional and curative objects during the late nineteenth and early twentieth centuries. Thus, as will be argued in what follows, these hilye bottles in essence provided a new kind of Prophetic pharmacon, whereby Muhammad was reified - and symbolically ingested - by pious devotees, who conceptualized the Prophet's flask-encased verbal icon as the ultimate elixirvitae.

Since hilye bottles remain unexamined to the present day, a detailed analysis of their constituent forms, materials, and current states of preservation enables a better understanding of their symbolic functions and uses in late Ottoman Islamic devotional spheres.

Measuring $42 \mathrm{~cm}$ in height and topped with a (now lopsided) golden finial wrapped in a green silk ribbon, the first bottle is the largest in the group (Figure 18.2). Its interior is lavishly decorated with a vertical gilt rod, whose horizontal posts provide perches for dangling pearl ornaments. Other decorations fill the interior of the blown glass bottle; these include wicker branches, flowers made of brown and white fabric, and round beads made of green and red plastic, the latter a modern material. This panoply of decorative items comes together to form what we might call hilye installation art, itself intended to remain undisturbed thanks to the wax sealing the flask's neck. In this instance, the bottle's contents were meant to remain inaccessible.

Two of the four bottle's sides display the hilye, which records 'Alì's verbal description of Muhammad's physical and moral characteristics set into the diagrammatic format invented by the famous seventeenth-century Ottoman calligrapher Hafiz Osman (d. $1698 \mathrm{CE}) \cdot{ }^{5}$ Here, the typical hilye layout, with its

5 On hilye panels and paintings, see in particular Taşkale and Gündüz, Hz. Muhammed'in Özellikleri; Zakariya, "The Hilye of the Prophet Muhammad", 13-22; and Stanley, "From Text to Art Form in the Ottoman Hilye". 


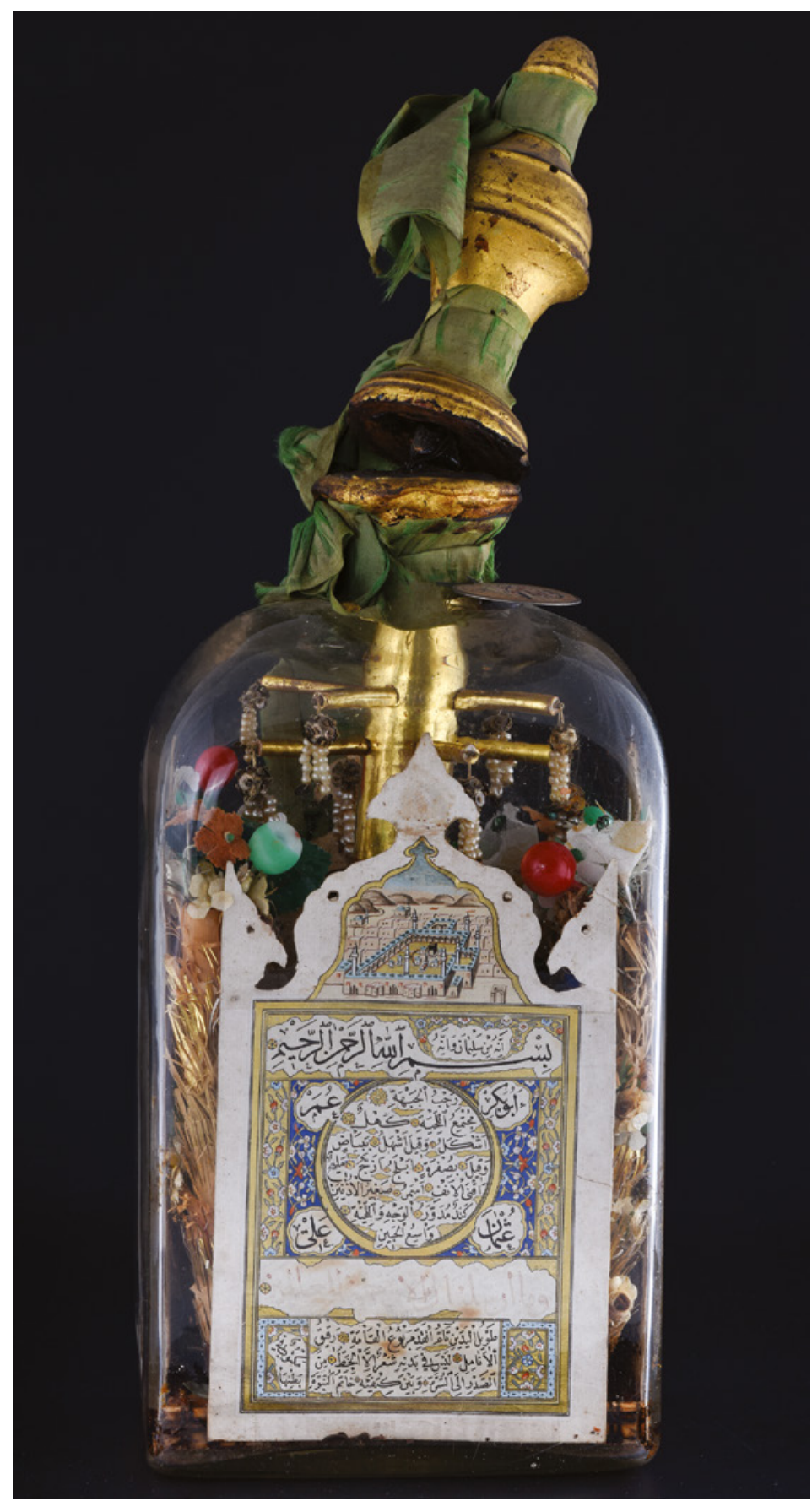

FIGURE 18.2 Glass bottle with a hilye showing a depiction of Mecca, Ottoman lands, late 19th century. Topkapı Palace Museum Library, Istanbul, G.Y. 1413 
central omphalos (göbek) surrounded by medallions inscribed with the names of the four rāshidūn, is readily recognizable (Figure 18.3). Also quite typical is the inclusion of depictions of Mecca and Medina as top pieces as well as the Qur'annic verse praising Muhammad with the exclamation: "We sent you as nothing but mercy to all the universes" (21:107). More intriguingly, the besmele at the top of each hilye panel is surmounted by the Qur'ānic expression "Indeed it is from Solomon" (27:30). Because this clause can refer to Solomonic white magic, it is frequently found inscribed in Islamic talismans, chief among them the "seal of Solomon."

The Solomonic statement hints at the item's apotropaic use, and indeed hilyes were often used as talismans in Ottoman lands during the eighteenth and nineteenth centuries. Some, like the panel of cut-out (kat' $\iota$ ) work in the Sadberk Hanım Museum, include a number of talismanic statements and devices that promise protection to their owners and viewers. ${ }^{7}$ Still other hilyes were printed from metal plaques, as attested to a number of items preserved in the Walters Art Museum ${ }^{8}$ and the Haluk Perk Collection (Figure 18.4). ${ }^{9}$ Known as matrices, these metal plaques were engraved with textual and visual content, and were used to produce printed amulets. Just like other hilyes painted on panels or included in illustrated manuscripts, these metal objects were outfitted with designs and Qurānic verses believed to be particularly protective.

The first hilye bottle's talismanic and prophylactic qualities are further elucidated in the verses of Persian poetry affixed to the bottle's two other sides (Figures 18.5 and 18.6). The verses include some misspellings, thereby suggesting Ottoman authorship, and read as follows:

Oh Lord, place this divine shadow on the throne of perpetuity, And illuminate the sun of the royal sky in perpetual heaven.

Whoever keeps this beautiful hilye at home will be saved from spiritual suffering, poverty, sadness, persecution, and calamities. When God, His pure being, out of mercy allows it, Then without a doubt [the owner] benefits very much from his [the Prophet Muhammad's] descriptions.

6 On the seal of Solomon, see Dawkins, "The Seal of Solomon", 145-50.

7 Taşkale and Gündüz, Hz. Muhammed'in Özellikleri, 21; Çağman, Kat'ı, 250-51; and Bilgi, Gönülden Bir Tutku, 81 .

8 See the talismanic hilye plate (a metal matrix to stamp talismans), which currently is incorrectly identified as a pilgrimage certificate, at: https://art.thewalters.org/detail/11417/plaquefor-printing-a-pilgrimage-certificate/ (accessed February 28, 2021).

9 The talismanic plaque illustrated in Figure 18.4 is unpublished; for a similar example in the Haluk Perk Museum, see Perk, Osmanlı tılsım mühürleri, 36 f. cat. no. 1.1.o1. 


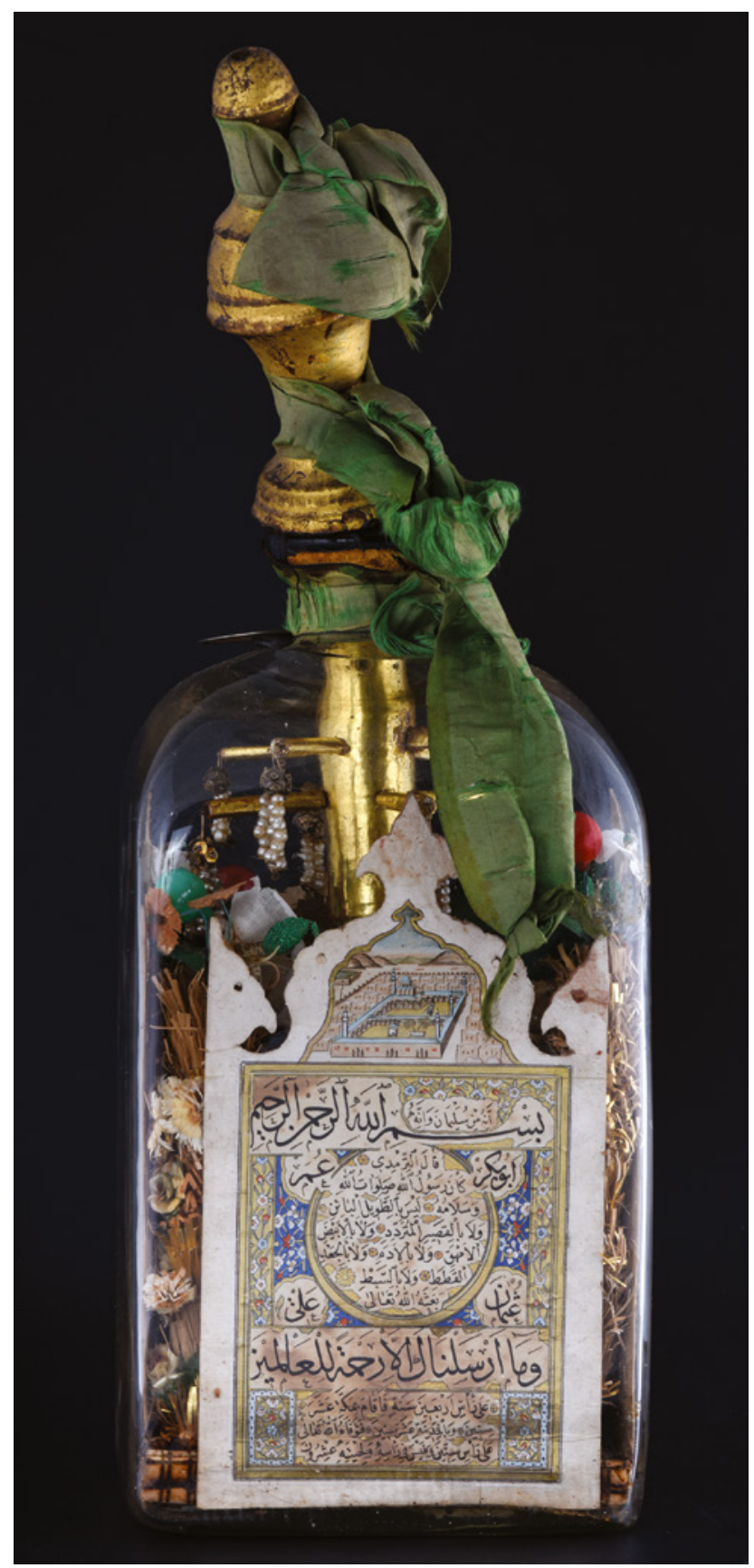

FIGURE 18.3 Glass bottle with a hilye showing a depiction of Medina, Ottoman lands, late 19th century. Topkapı Palace Museum Library, Istanbul, G.Y. 1413 


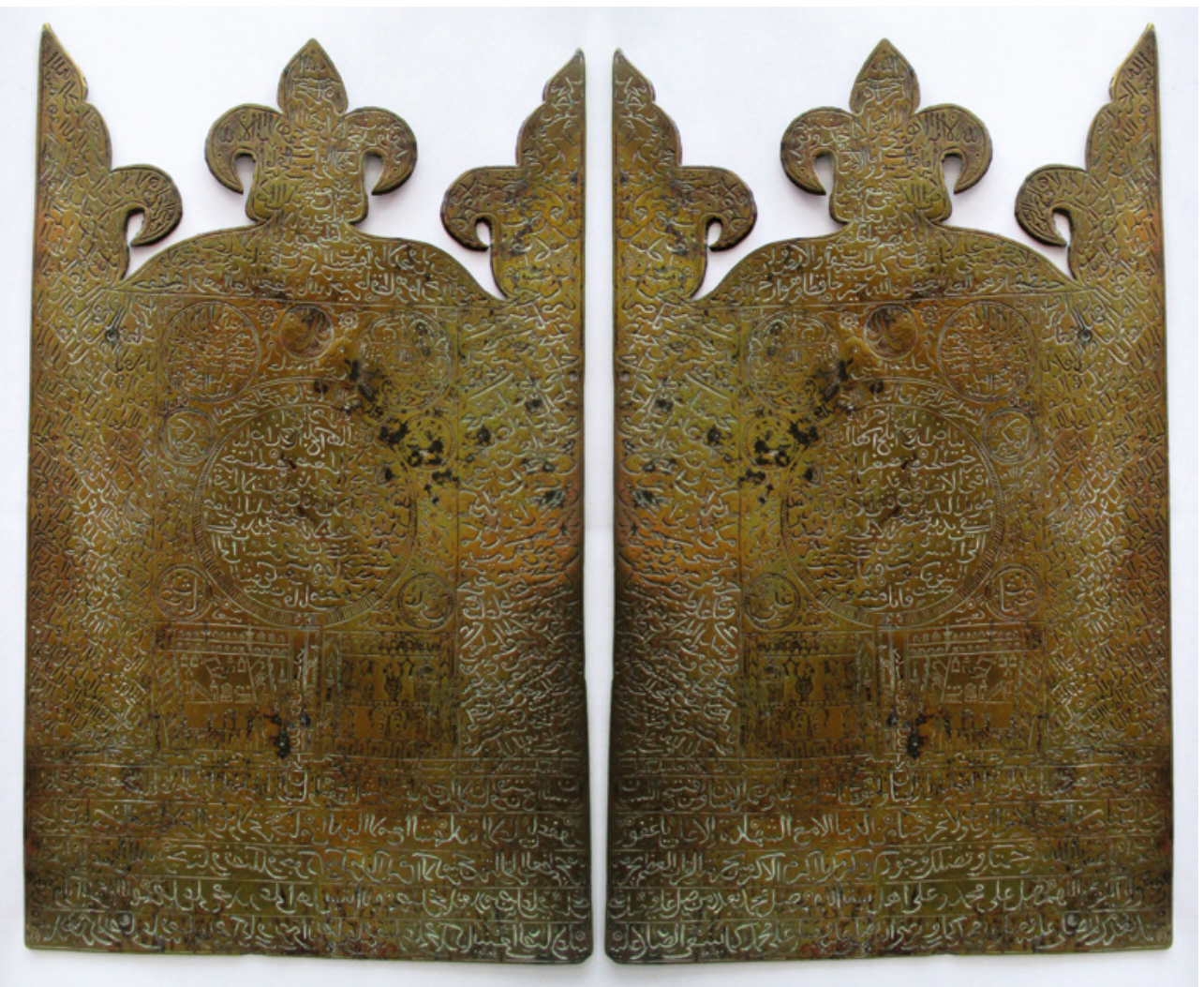

FIGURE 18.4 Metal plaque containing a hilye of the Prophet and other amuletic inscriptions and designs, Ottoman lands, late nineteenth or twentieth century. Halukk Perk Collection, Istanbul, unnumbered. Left: the original printing plaque, with writing in reverse; and right: the plaque digitally flipped to render the script legible

The first panel of Persian poetry praises God through a series of celestial and cosmic metaphors, while the second panel addresses the bottle's owner directly by reminding him or her of the hilye's shielding capacities. Moreover, by stressing the supremacy of God, these verses make it clear that this item is not to be considered a tool in the practice of black magic, but rather a permissible form of harnessing protective energies according to the Solomonic method. As a result, the first hilye bottle encases a verbal icon of the Prophet Muhammad and turns it into an amuletic form of installation art meant to protect individuals within a domestic setting.

The second hilye bottle similarly preserves two icon panels, but here the paper folios are mounted onto wooden boards separated by a long rod wrapped 


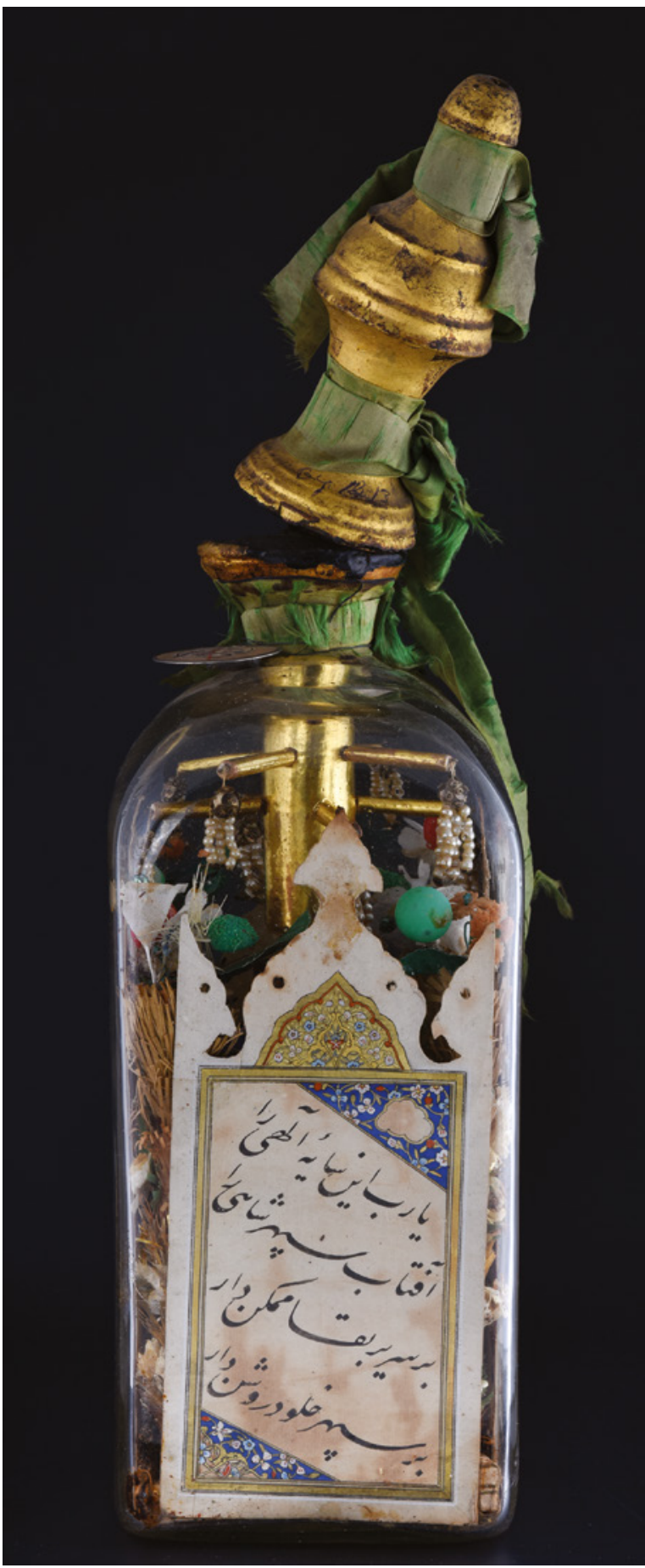

FIGURE 18.5

Lines of Persian poetry in the hilye bottle illustrated in figures 18.2 and 18.3 


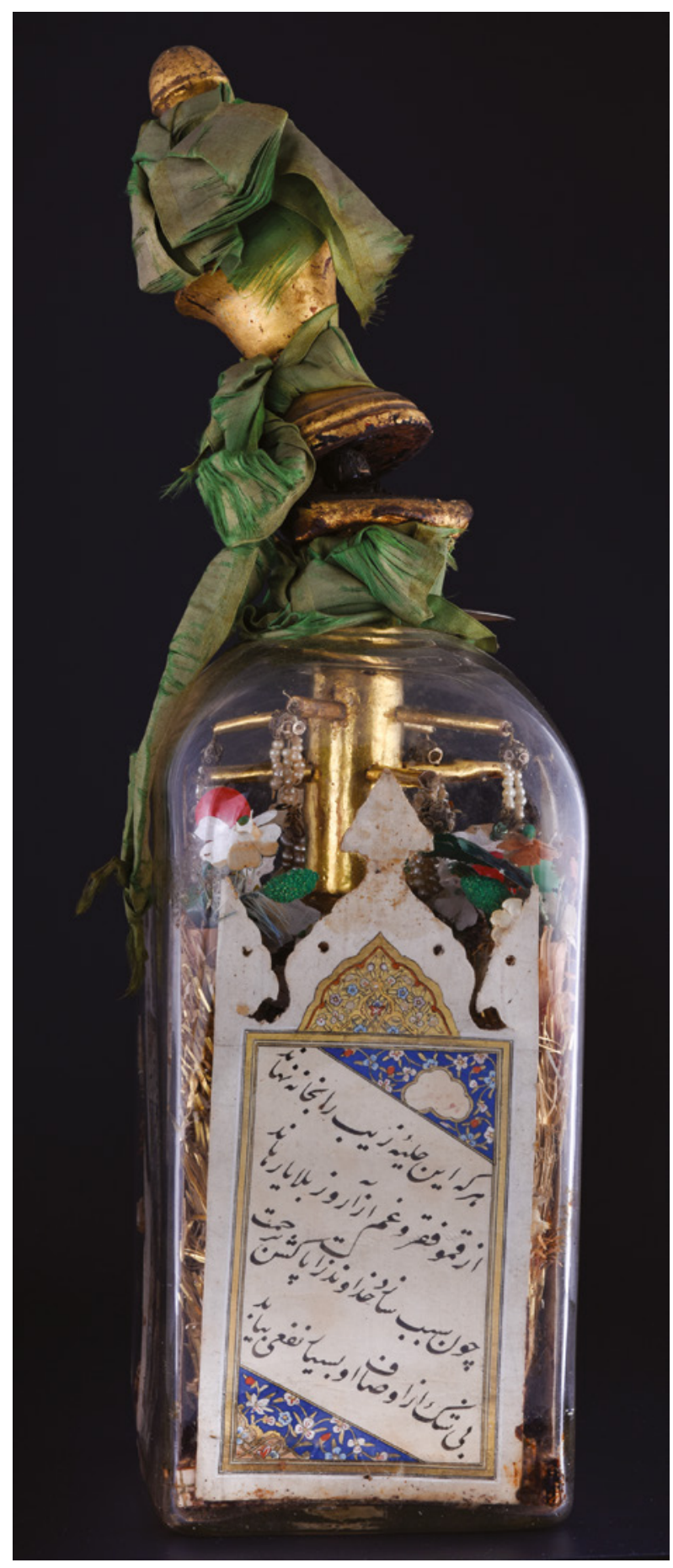

FIGURE 18.6

Lines of Persian poetry in the hilye bottle illustrated in figures 18.2 and 18.3 


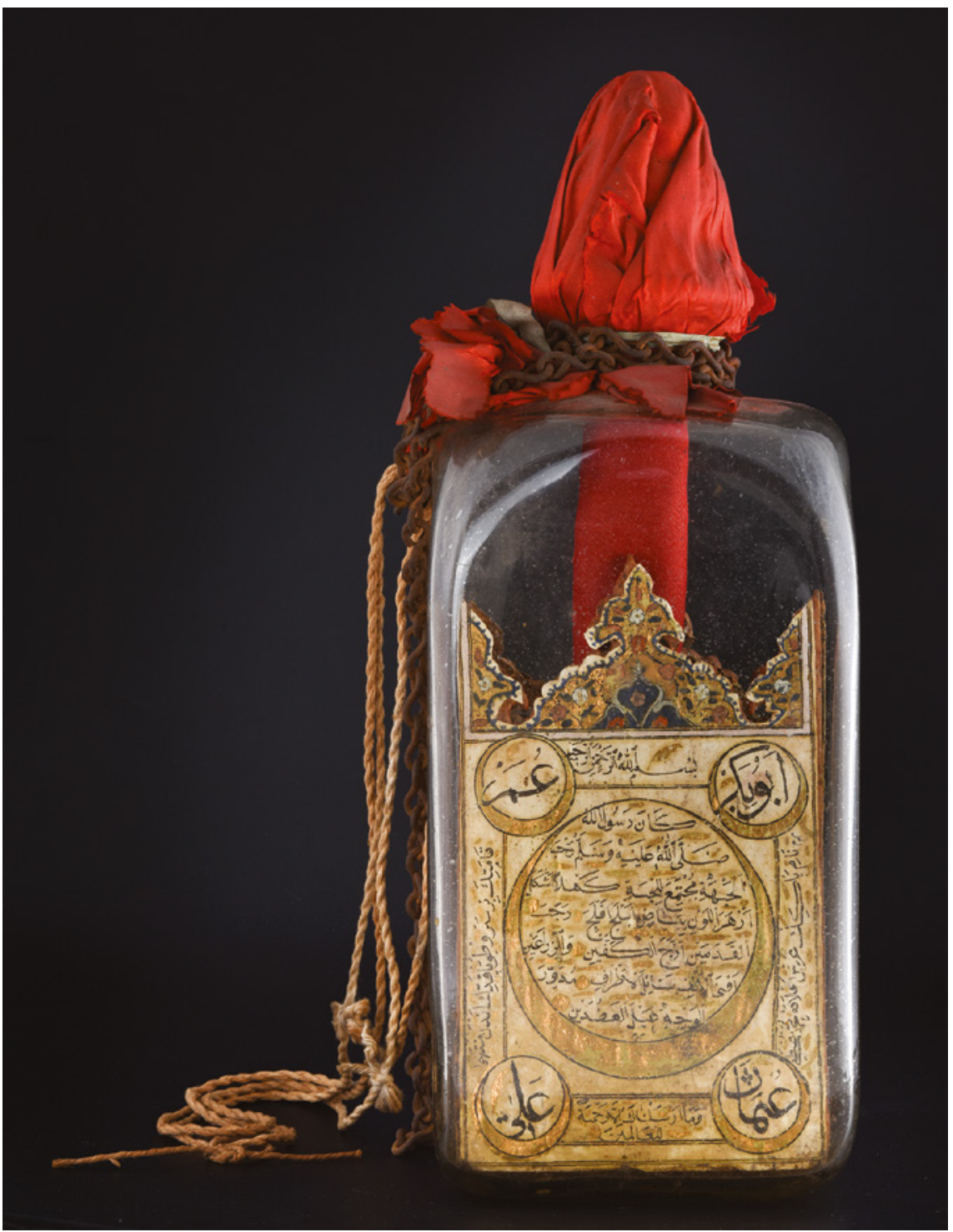

FIGURE 18.7 First side of icon, hilye bottle with a stopper covered in red silk and a rope and chain wrapped around its neck, Ottoman lands, late 19th century. Topkapı Palace Museum Library, Istanbul, G.Y. 954

in red silk, a detail to which we will return subsequently (Figure 18.7). In addition, the bottle is outfitted with a rope and metal chain, and so appears to have been suspended or carried on occasion, rather than permanently exhibited on a flat surface such as a table or shelf. The hilye text is largely placed within an 


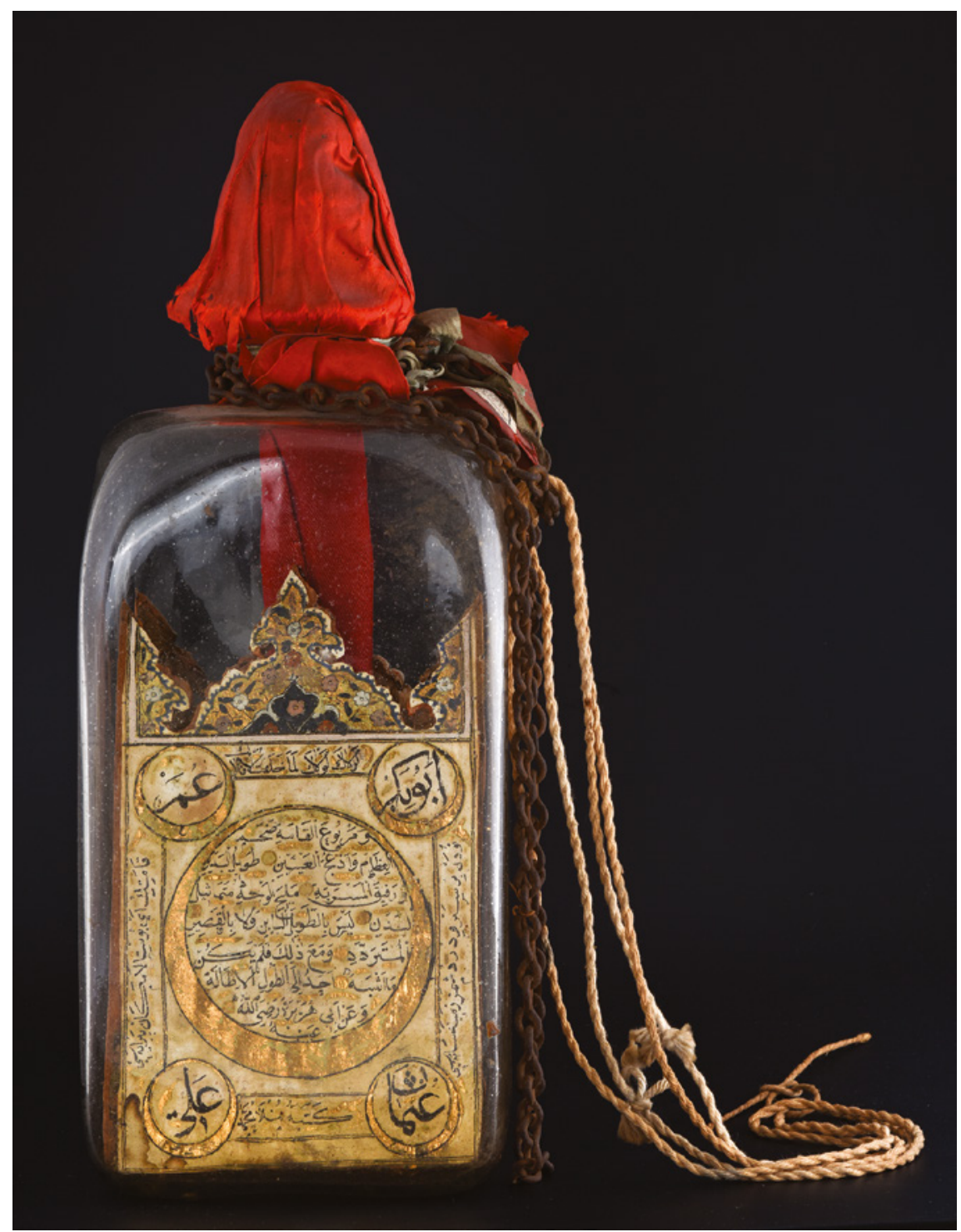

FIGURE 18.8 Second side of icon illustrated in figure 18.7

omphalos girdled by a gold crescent, surrounded once again by the rāshidūn. In this instance, however, no mention of Solomon is made. Rather, the first panel's horizontal registers running along the frame include the besmele and the Qurānic verse of mercy. The second panel (Figure 18.8) also includes at its top the famous "Law Lāka" hadīth qudsi that states: "Were it not for you [oh 
Muhammad], I would not have created the heavenly spheres." It also provides the signature of the calligrapher, a certain Munlā (Molla/Mevla) Muhammad.

Inscribed in their vertical frames, these two hilye panels are augmented with Ottoman devotional poetry in honour of the Prophet. Although their metre is not entirely correct, the first two verses read as follows: "Your pure name is on the highest throne, Muhammad Muștafā / Your figure is [like] the cypress of Tuubā, your stature reaches from there to Muntahā" (Nām-i pākın 'arş-ı a lă'da, Muhammed Muștafā / Kāmetin bir serv-i Tübā ḳaddin andan Müntehā). Here, the Prophet is said to have his name inscribed on God's throne - a motif rather pervasive in Islamic ascension texts and poems - and his cosmic stature is so vast that it is said to stretch from the upside-down Tuba Tree (shajarat al-Ṭübā) to the Lote Tree of the Limit (sidrat al-muntaha $\bar{a}$. The next two verses, although they include misspellings, can be identified as the work of the famous sixteenthcentury Ottoman poet Zati (d. $1546 \mathrm{CE}$ ). They exclaim: "Oh, Embellishment of the Garden of Illocality, your stature is a cypress of light; it casts no shadow on the ground" (Kämetin ey bustān-ı lā-mekān pīrāyesi / Nürdan bir servidür düşmez zemine sāyesi).$^{10}$ In these verses, the Prophet Muhammad is described as a fine-figured entity made from light that bears no shadow as well as an embellishment of a heavenly garden not bound by time or space.

Taken altogether, the figures of speech and motifs used in all four Ottoman Turkish verses added to this hilye make clear reference to Muhammad's celestial ascension, the celebration of which occurred in palace quarters to the accompaniment of praise poetry and the illumination of hanging lamps (kandils). Perhaps it can be surmised, then, this hilye bottle was suspended or ritually carried during mi'rac, mevlid, or other religious festivities held in Topkapı Palace. ${ }^{11}$

Other evidence for its potential use is suggested by the vertical rod that resembles a perfume dauber. When rocked back and forth by its removable cap, this interior rodule scrapes the backsides of both hilye panels, in the process producing a gold dust that could have been collected and extracted from the bottle thanks to the slightly dampened red silk fabric (Figure 18.9). Indeed, the gold flecks at the bottom of the flask do not appear to be the haphazard result of wear and tear over time. Rather, it becomes clear from the object's material

10 On Zati on his poetry, see Gibb, A History of Ottoman Poetry, III, 47-69, especially p. 54; and for the first verse of this poem, see Başlangıcından günümüze kadar büyük Türk klâsikleri, vol. 3, 296, Gazel xv, line 1.

11 For a discussion of hanging lamps and praise poetry in Ottoman Islamic festivities, see Zarcone, "Mevlid Kandili", 307-20. 


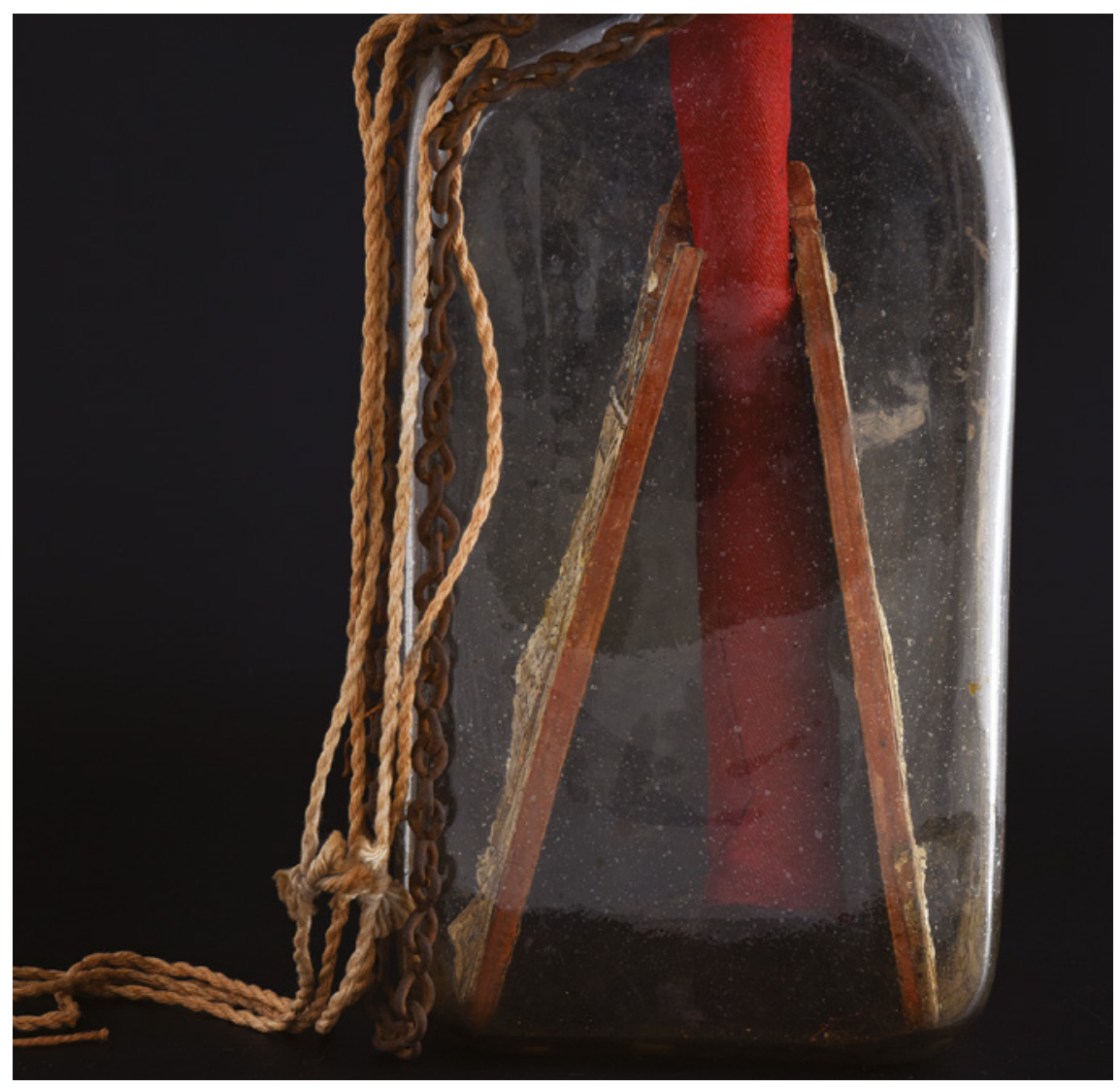

FIGURE 18.9 Detail of the backsides of the hilye panels included in the bottle illustrated in figures 18.7 and 18.8

makeup that the main goal of the glass bottle consisted in the production of gold hilye dust. In order to produce an auric powder, the artisan affixed goldpainted papers to the back of both wooden hilye panels: one still retains its gold pigments in relatively good condition while the second has witnessed the neartotal loss of its gilt backing, no doubt due to repeated chafing at the same angle. Thus, unlike the first hilye bottle that was intended for artful display and protection in the home, this item was meant to be used in some fashion or another.

The third and last hilye bottle must have fulfilled a similar function (Figure 18.10). It contains only one wooden panel whose two sides are affixed with folios containing Muhammad's verbal icon. Its first side includes the title "The Features of our Beloved" (șifat habibinā) while its second side includes some of the names of the Prophet's ten companions who were promised paradise 


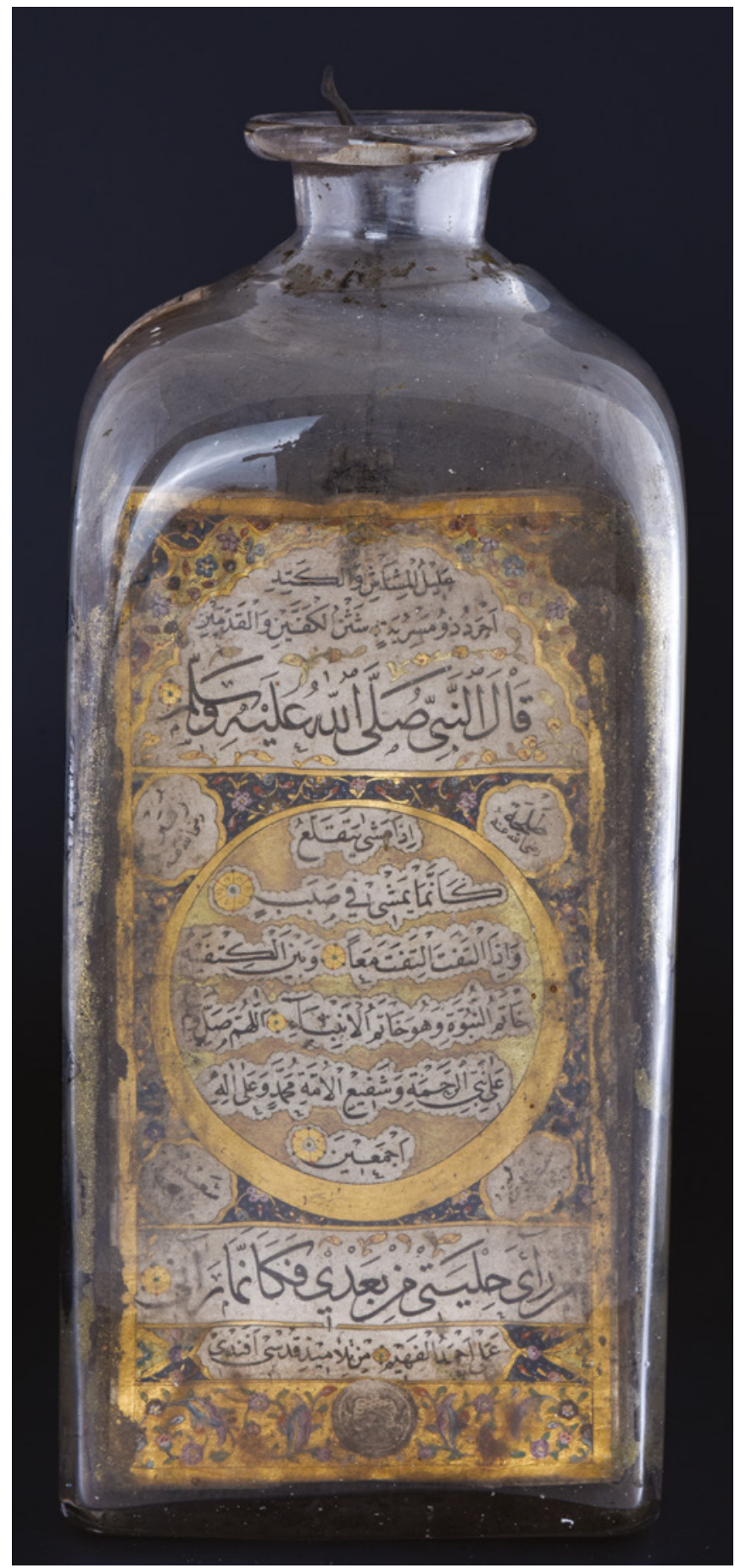

FIGURE 18.10

Hilye bottle with a metal wire attached to the verbal icon, Ottoman lands, late 19th century. Topkapı Palace Museum Library, Istanbul, G.Y. 429 
(al-'ashara al-mubashshara), itself a widespread Sunnī Ottoman textual motif used in contradistinction to Safavid praises of the twelve Shīi imams. ${ }^{12}$

Several other details are noteworthy. First, and most conspicuously, this bottle is neither sealed shut nor is it provided with a removable cap, like the first two examples. Instead, the hilye panel is affixed to a metal wire that curves in the flask's neck, and rises slightly above the opening of bottle. This metal handle must have been used by an individual to set in motion, shake, or rock the hilye within its container, which resulted in visible interior scrape marks and a loss of gold pigment on the bottle's lateral sides. Those very same sides carry deeper symbolic importance, as they are covered in monumental inscriptions that proclaim: "Verily, He [God] illuminated the world with the light of Muhammad" (Figures 18.11 and 18.12). Here, God's creation of the Prophet's light as a radiant flux appears equated with gold pigment ornamenting the flask's sides. This lustrous, high-luxury material in turn could be transformed into gold dust or powder by setting Muhammad's verbal icon to motion within the glass container.

A close examination of these three hilye bottles leads to a few preliminary conclusions. Depending on use and location, such items could be shut closed, opened on demand, or permanently kept ajar. One functioned as a Muhammad-centred talismanic art object intended to protect an individual and his/her home. In the latter case, no further interactions were necessary. In other cases, however, a chain and rope suggest more ritualistic uses, including carrying or suspension in festive commemorations of the Prophet or other religious holidays, including the celebration of his birth or celestial ascension. In such cases, a removable cap and silk-covered stopper enabled the collection and extraction of gold flecks, rubbed off the gilt papers lining the hilye panels' back sides. Last but not least, in at least one instance, this gold dust or pigment is equated with the nür Muhammad, itself the primordial and generative element used by God to create the entire world. ${ }^{13}$

Taken all together, these newly uncovered hilye bottles raise a number of questions concerned with late Ottoman artistic traditions as these intersect with devotional practices dedicated to the Prophet Muhammad, especially in a larger Constantinopolitan setting. Perhaps the two most important queries that arise are: first, what were the uses and purposes of creating gold dust, and,

12 For a discussion of the al-'ashara al-mubashshara as an Ottoman Sunnī retort to the Safavid emphasis on the Shīīi imams, see Gruber, The Praiseworthy One, 292-98, especially figures 5.19 and 5.22 .

13 On the nür Muhammad, see Rubin, "Pre-existence and Light"; and Gruber, "Between Logos (Kalima) and Light (Nür)". 


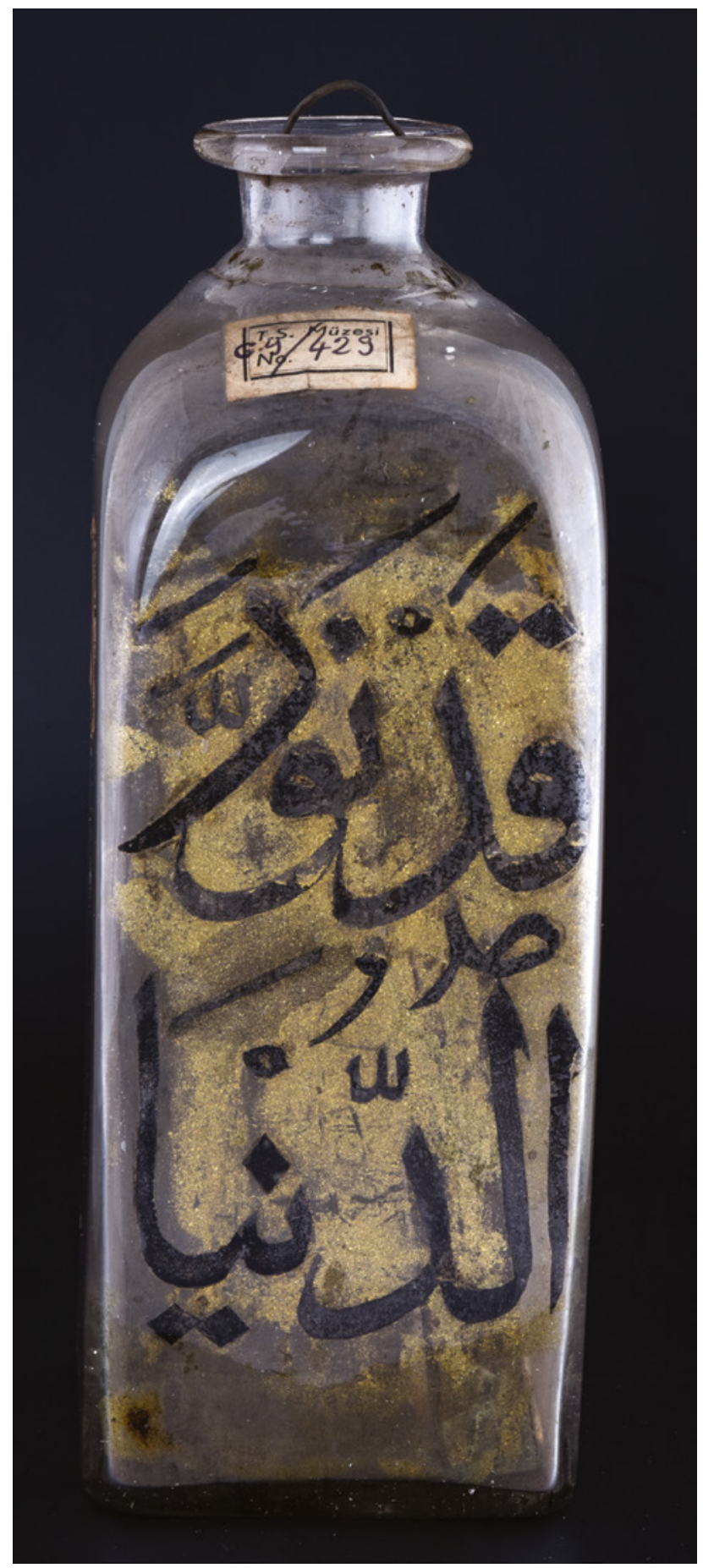

FIGURE 18.11

Inscription on the first side of the hilye bottle illustrated in figure 18.10 


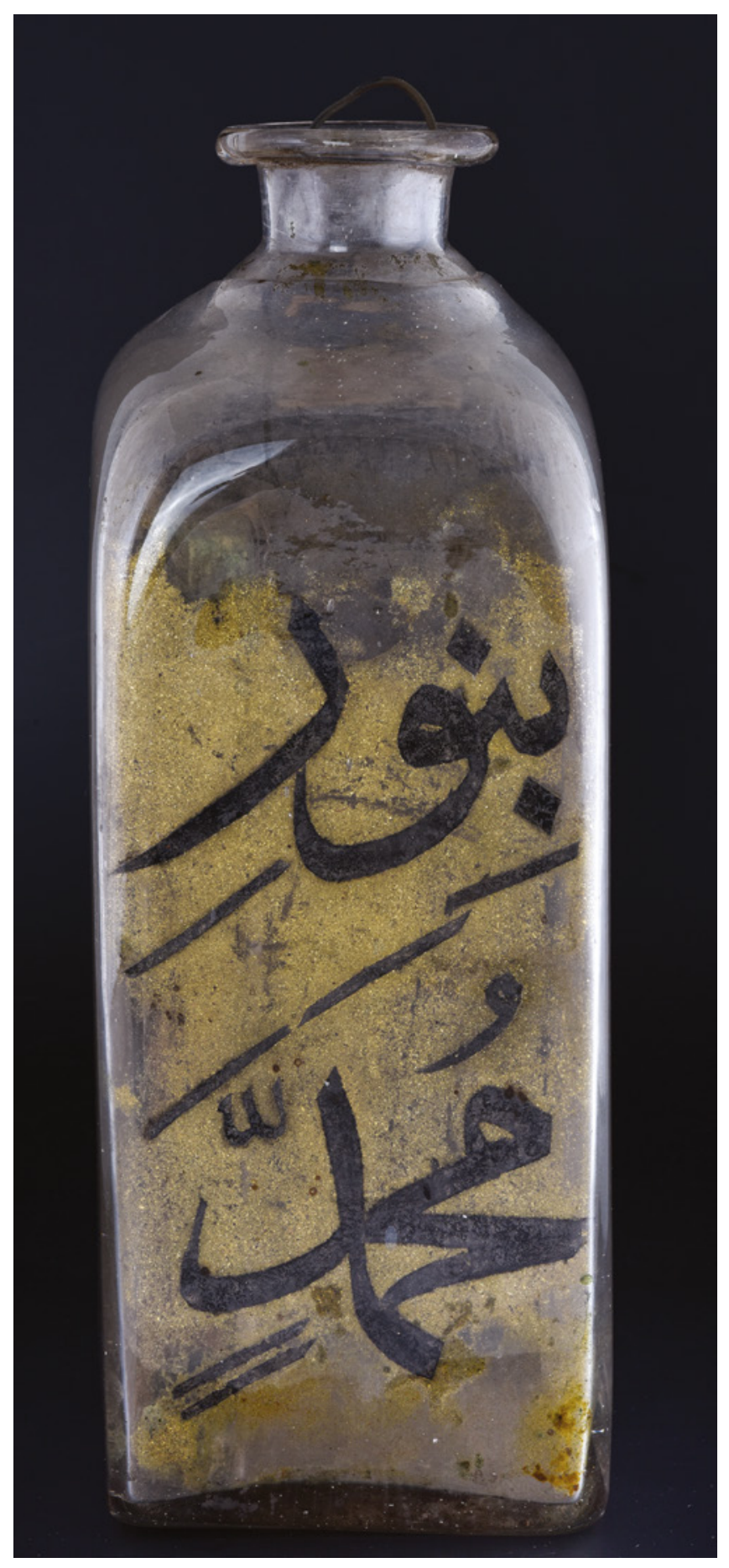

FIGURE 18.12

Inscription on the second side of the hilye bottle illustrated in figure 18.10 
second, what are the origins and hence symbolic meanings of these icon bottles? Examining related artistic evidence can help us expand and refine our range of possible interpretations, chief among them the bottles' likely use in late Ottoman magico-medicinal practices that involved the mixing of sacred dust or soil with holy water in order to produce liquid suspensions and curative potions believed saturated with Prophetic blessings or baraka.

During the eighteenth and nineteenth centuries, hilyes were believed to protect individuals, their belongings, and their homes. Their talismanic energies were believed latent and activated through a number of practices, most especially their viewers' gaze, rubbing, and kissing. A number of late Ottoman illustrated prayer books include specific directions on how to make use of such optic and haptic practices, which were believed to unleash the dormant blessings contained in Muhammad's verbal icon, his relics, and his other marks and traces. ${ }^{14}$

For example, one devotional miscellany transcribed during the eighteenth or nineteenth century includes a double-page depiction of the Prophet's hilye topped by the widespread invocation seeking refuge from the cursed devil (Figure 18.13). The icon's position as a potent source of protection is further strengthened by the presence of a short instructional text attributed to the famous hadīth compiler al-Tirmidhì (d. 892) located at the bottom of each hilye panel and continuing on the manuscript's subsequent folios. Here and in other cases, ${ }^{15}$ al-Tirmidhī is recorded (in Ottoman Turkish) as informing the reader that the Prophet's seal contains many virtues or merits. Among them, we are told that whoever looks at it in the morning after having performed ablutions will be protected from all disasters and catastrophes until the end of the day. The same holds true for the beginning of the month and year as well as at the launch of a trip. Finally, whosoever gazes upon it during the year of his death will end his life in faith by the grace of God the Almighty. In still other prayer books, al-Tirmidhì is cited on the necessity of rubbing (sürmek) the seal of prophecy to one's face or eyes, thus proving that looking intensely at Muhammad's icon and his other signs, combined with the scraping of their pigments, was believed to help the pious believer guard against tragedy.

\footnotetext{
14 On this subject, see Gruber, “'Go Wherever You Wish, for Verily You are Well Protected".

15 See the nineteenth-century "seal of prophecy" inscribed with al-Tirmidhïs statement in Aşk-ı Nebi: Doğumunun 1443. Yılında Hz. Peygamber, 128, cat. no. 23 (Topkapı Palace Library, G.Y. 1500).
} 


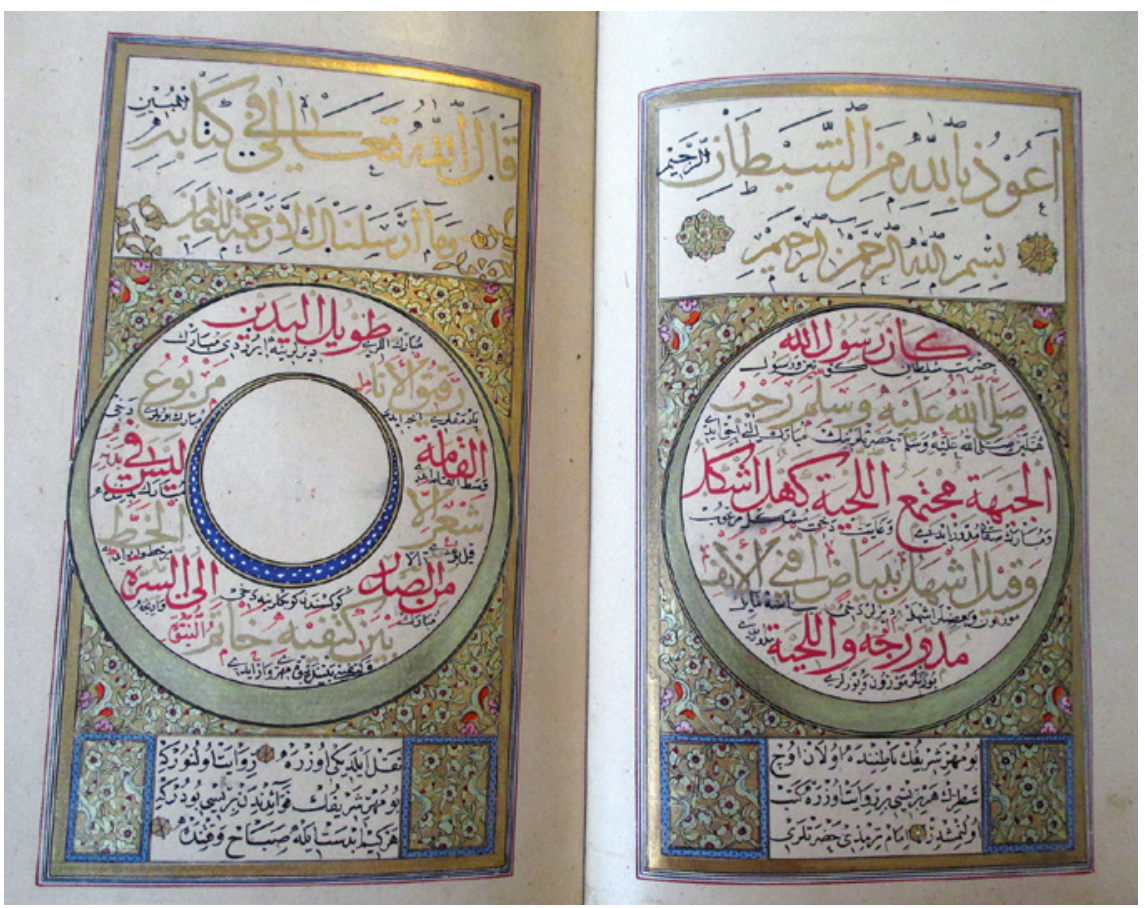

FIGURE 18.13 The Prophet Muhammad's hilye with directions of use attributed to al-Tirmidhī, included in a prayer book, Ottoman lands, 18th or 19th century. Topkapı Palace Museum Library, Istanbul, E.H. 996, folios 1ov-11r

Such ardent forms of caressing sacred images also extended to depictions of Mecca and Medina, both of which are intimately associated with the Prophet's life and career. ${ }^{16}$ A number of late Ottoman manuscripts of al-Jazūli’s (d. 1465) Dalāil al-Khayrāt (Proofs of Good Deeds) and other prayer books include double-page paintings of the two holy cities, at times tarnished with smear marks that appear as if strategic strikes. For example, one late eighteenthcentury copy of al-Jazūlī's text displays a loss of black pigment from the kiswa cloaking the Kaba as well as blue-and-white smudges tainting the dome over the Prophet's grave in Medina. ${ }^{17}$ Another contemporary copy of the Dalä'il al-Khayrāt shows similar abrasions, which appear as if caused by the wet flick of the finger first placed above the dome and then curved kinetically across

16 On this topic, see Göloğlu, "Touching Mecca and Medina”.

17 See the rubbed images of Mecca and Medina within a Dalä'il al-Khayrāt made in $1207 \mathrm{AH} /$ $1793 \mathrm{CE}$ now held in the Ekrem Hakkı Ayverdi Collection, Istanbul, viII/4, folios 28v-29r. 
the grilled chamber containing Muhammad's tomb (Figure 18.14). And still another late Ottoman illustrated manuscript of the same text suggests that viewers scraped pigments off of paintings of Mecca and Medina with great vigour, perhaps with the ultimate aim of collecting these sacred pigments on their fingers and lips (Figure 18.15). ${ }^{18}$

From Muhammad's seal of prophecy to depictions of Mecca and Medina, the painterly evidence thus points to late Ottoman practices of rubbing and kissing sacred images - along with the collecting and/or ingesting of the pigment debris - associated with the Prophetic corpus and presence.

Such physically enacted devotions are supported by textual evidence as well. For example, writing during the seventeenth century, the Ottoman explorer Evliya Çelebi (d. 1682) records in his Seyahatname (Travel Book) the pietistic engagements of pilgrims in Mecca and Medina, including his own. Launching into his multi-volume oeuvre, he first pleads God to protect him during his sojourn with the rhetorical question: "Might I roam the world? Might it be vouchsafed to me to reach the Holy Land, Cairo and Damascus, Mecca, and Medina, and to rub my face at the Sacred Garden, the tomb of the Prophet, Glory of the Universe?"19 In Evliya Çelebi's introductory remarks, it appears as if the ultimate goal of his journey is none other than the overlaying of his visage with a Prophetic patina extracted from the blessed soil, textiles, grille, or other materials anointed by Muhammad's inhumed body.

Arriving in Medina, Evliya Çelebi then makes his way to the railing encircling Muhammad's tomb, telling his reader that: "There I kissed the threshold, prayed beseechingly, and knelt down." ${ }^{20}$ He then petitioned the Prophet for intercession and nearly fainted. Besides osculating the grille, he also kissed the ground at Muhammad's tomb in Medina, all the while asking for his intercession. $^{21}$

The pious traveller also records practices of devotional rubbing, above all in and around Medina. For instance, he includes a short description of a small shrine, known as "The Station of the Noble One" (makam-i hazret), located outside of Medina, shaped like a small prayer niche and housing the impression of the Prophet's head. There, he goes on, "pilgrims rub their faces (yüz sürerler) on this holy place."22

\footnotetext{
18 Göloğlu, "Linking, Printing, and Painting Sanctity and Protection", figure 8.

19 Gemici, "Mecca in the Seyahatnâme", 146.

20 Gemici and Dankoff, Evliya Çelebi in Medina, 30-31.

21 Gemici and Dankoff, Evliya Çelebi in Medina, 105.

22 Gemici and Dankoff, Evliya Çelebi in Medina, 26-28.
} 


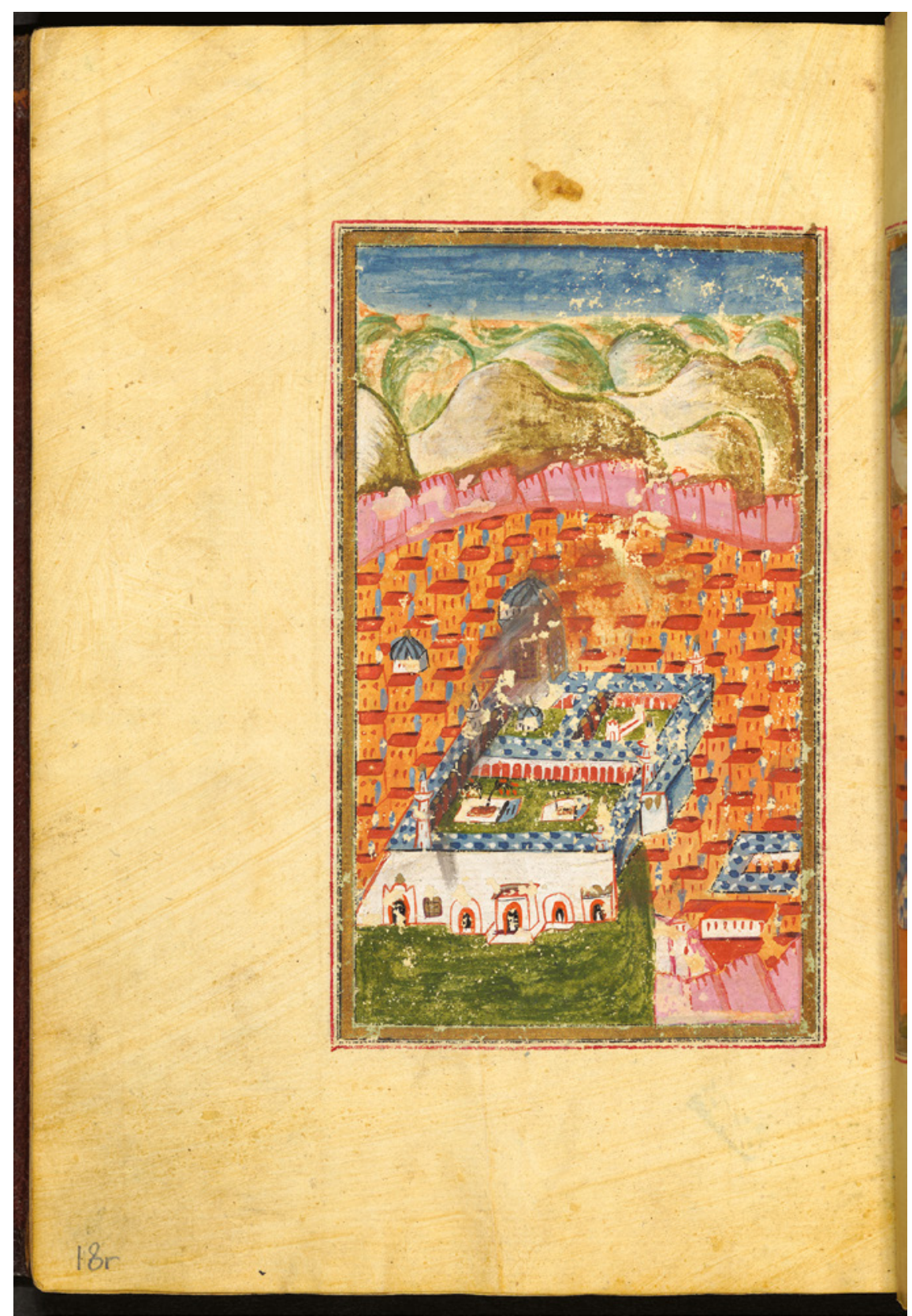

FIGURE 18.14 A depiction of Medina showing smudges over the Prophet Muhammad's tomb, al-Jazūlī, Dalāil al-Khayrāt, Ottoman lands, late 18th century. Museum of Islamic Art, Doha, MS. 419.2007, folio 18r 


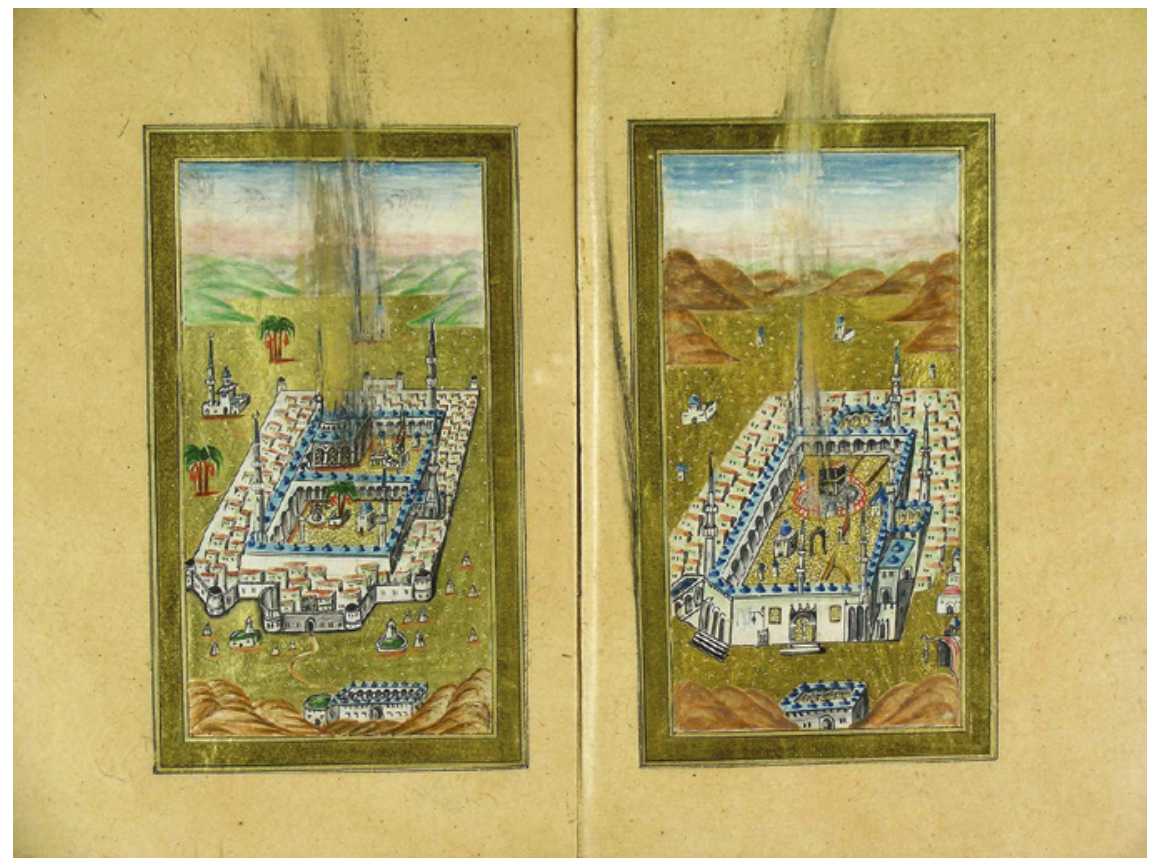

FIGURE 18.15 A heavily smudged double-page painting of Mecca and Medina, al-Jazūlī, Dalā’il al-Khayrāt, Süleymaniye Library, Istanbul, Hacı Mahmud Efendi 3986, folios 12v-13r

Such popular practices of kissing and rubbing were not at all frowned upon or prohibited at the time. Rather, they were actively sponsored by royal Ottoman patrons who lavished great gifts upon Islam's holy cities and even ordered the construction of new gates to the Medina mosque, including one inscribed with the poetic verses: "God forbid that he who rubs his face on your grave should not go free."23

Ottoman devotees' practices of kissing the kiswa and Black Stone in Mecca along with the rubbing of soil and the golden grille in Medina in order to secure the blessings and intercession of God and Muhammad also appear to have occurred within these sites' visual representations, as the painterly evidence strongly suggests. Although it is clear that such images were touched in various ways, one question still lingers: where did the now-missing pigments of this materia prophetica go? Upon affectionate kissing, did these pigments mix in with saliva and were they thus ingested by the faithful? Were the pigments

23 Gemici and Dankoff, Evliya Çelebi in Medina, 52-53: Ḥāsha li-llāh ḳabrine yüz süren āzād olmaya. 
smudged with wet fingers and then perhaps touched to the believer's lips or tongues? Or were they collected as Prophetic ingredients to be mixed in with other liquids or potions? In other words, what are the whys and wherefores of these fugitive pigments, and how might they shed new light on the meanings and functions of hilye bottles?

I would like to suggest that these bottles - just like other contemporary devotional icons devoted to the Prophet ${ }^{24}$ - provided a material mechanism to make and gather gold pigments. The fact that one of them mentions the nür Muhammad leads us, in part, to associate such pigments with the Prophet's primordial light. That two bottles included hilyes meant to scrape at the inside walls further strengthens this hypothesis. In addition, during the late Ottoman period, collecting the water run-off from the ritual washing of the Prophet's footprint and mantle was a well-known practice in Ottoman palace quarters. This Prophetic liquid was then preserved in small flasks, imbibed to break the evening fast during Ramadan, and administered as a curative potion throughout the year. ${ }^{25}$ Libations that came into contact with Muhammad's relics were understood as the ultimate panacea, and such magico-medicinal liquids quite possibly included other tonics and potions into which were mixed gold Prophetic precipitate extracted or poured from hilye bottles.

Textual sources support the alchemical belief that gold in particular contained transformative and restorative powers, a belief that appears to have been relatively common in late Ottoman lands. For instance, one manuscript that records the recipes for medicines and potions produced in the Topkapi Palace pharmacy includes various antidotes, potions, pills, pastilles, syrups, ointments, and balms to help with a variety of ills. ${ }^{26}$ Most relevant for our purposes, this royal pharmacopeia also includes a number of recipes for compound medicines made from precious metals and stones, including gold, silver, ruby, amber, and pearl.

One recipe that stands out is the so-called macūn-ı kırmız, or red potion or paste. ${ }^{27}$ Among other things, its ingredients include apple juice, rose water, sugar, amber, lapis, pearl, cinnamon, musk, aloe, ruby, and gold and silver leaf (altun varak and gümüs varak). We are told that its curative and restorative powers are many and that, as a general cure-all, it is especially useful in helping with problems related to the head, heart, liver, and stomach. Moreover, it

24 For a study of devotees rubbing and kissing visual representations of the Prophet in Ottoman traditions in particular, see Gruber, "In Defense and Devotion", 95-123.

25 For a discussion of the topic, see Gruber, "A Pious Cure-All", 134-35.

26 Terzioğlu, Helvahane Defterive Topkapı Sarayında Eczacılı.

27 Terzioğlu, Helvahane Defteri ve Topkapı Sarayı'nda Eczacılı, 69, no. 51b. 
is believed to cure forgetfulness and vertigo; to make the face lighter in tone; to help pregnant women to prevent miscarriages; to lessen colic and indigestion in children; and to alleviate illness during plague and other epidemics. The treatise also gives directions for production of this panacea containing crushed gold leaf, and its use, including the boiling of liquids, the pounding in of various ingredients, the draining of water and cooling in order to create a paste, the latter eventually preserved in jars. Whenever needed, this healing blend was doled out in small amounts and mixed in with sherbet to be imbibed by those suffering from a wide range of ailments.

This recipe's inclusion of gold leaf along with its mention of pounding its constituent ingredients suggests that the palace's pharmacy housed rare materials, including leaves of gold, which comprise a stable consolidation of this precious metal that then could be ground into a (more volatile) powder when demand arose to manufacture new potions. The use of gold leaf in the production of "red paste" also continued into the late eighteenth century, as attested to by a list of recipes drawn up in $1198 / 1784 .{ }^{28}$ Specified as exclusively reserved for the sultan, the recipe for ma'cūn-ı kırmı calls for the inclusion of a leaf of gold. This archival document is telling on at least two counts: first, it shows that the "red paste" consistently included a certain amount of gold and, second, that this paste was restricted to royal spheres only.

Gold pigments, flecks, and even debris are a hallmark of two of the hilye bottles, while one in particular includes a gold leaf backing that is now entirely lost due to pulverisation by the interior dauber covered in red silk. It is thus not unlikely that this dauber was moistened, and the gold flecks gathered, perhaps to be mixed into curative elixirs like the so-called "red paste." In such cases, the gold's therapeutic potential could be seen as exponentially more effective, having derived from the Prophet's blessed icon, itself encased in a pellucid, decanter-like vessel. ${ }^{29}$ Individuals in turn could ingest or imbibe this auratic precipitate, whose baraka possibly was thought to somatically fuse with the flesh and body of the believer.

Other extant objects support this hypothesis, among them jugs containing soil and dust gathered from the Prophet Muhammad's tomb in Medina as well as bottles preserving water extracted from the Zamzam well in Mecca. These containers pay tribute to the late Ottoman Muslim belief in the blessed and

28 Topkapı Palace Museum Archives, Istanbul, no. 93/1-3, document giving directions for the production of medicinal pastes bearing the summary title "Hekimbaşının hazırladığı ve kim tarafindan yazıldığı bilinmeyen macun tarifleri." I wish to thank Akif Yerlioğlu for drawing my attention to this document.

On the auratic qualities of glass vessels in general, see Liu, "Glass Containers' Aura". 
curative qualities of the two holiest cities of Islam, especially if their gathered natural matter - namely, soil, dust, and water - are preserved, ingested, and hence symbolically vivified within the physical body of pious Muslims. The belief in the curative power of certain substances also is attested to in other objects, among them magico-medicinal bowls and cups used in theurgical practices involving the Qur'ān, itself considered the "Best of Healers" (Q 17:82).

During the nineteenth century in particular, soil and dust from Medina were collected in jugs and vessels or else mixed in with straw and made into portable bundles, which could be worn as amulets (Figure 18.16). ${ }^{30}$ In addition, curative tablets containing the soil of Medina believed to be mixed with Muhammad's saliva - itself described as curing battle wounds and inflammations of the eyeballs, ${ }^{31}$ as well as having been mixed into the mortar of the dome of Hagia Sophia to stop it from collapsing ${ }^{32}$ - were promoted as all-purpose pills. One, for instance, includes the following inscription: "May the soil of our land and the saliva of some among us, God willing, be curative."33 Much like the dust and soil gathered from Muhammad's mausoleum and tomb, the gold powder preserved in and extracted from hilye bottles must have been considered similarly talismanic and salutary, especially if mixed into a liquid suspension involving the Prophet's saliva or water associated with the holy cities of Mecca and Medina.

In this regard, during late Ottoman times vessels were made to preserve holy water as well. For example, one jug includes a statement noting that it contained the water used to clean Muhammad's tomb, which was poured out or dried up over time. Sources likewise tell us that, upon the completion of the ritual cleaning of the Prophet's mausoleum, the remaining water was disposed

30 On jugs containing soil from the tomb of the Prophet, see Aydın, Pavilion of the Sacred Relics, 19o; on the amuletic bundles of soil and straw as illustrated in figure 18.16, see Mols and Vrolijk, Western Arabia in the Leiden Collections, 81; and on powder in magico-medical practices, see Flood, Technologies de dévotion dans les arts de l'Islam, 73-79.

31 On Muhammad's saliva mixed in with dust to cure ulcers and wounds, see Elgood, "Tibb-ul-Tabi or Medicine of the Prophet", 155; and Flood, "Bodies and Becoming", 469. A number of hadīth describe Muḥammad's spittle as healing wounded eyes and bodies, especially during the battles of Khaybar and Badr. These sayings are listed among Muhammad's "saliva miracles" in al-Yahsubi, Muhammad, Messenger of Allah, 160 and $178 \mathrm{f}$.

Ottoman chronicles describe Byzantine efforts to reinforce the church's dome after an initial collapse. Among such narratives, we are told that the Byzantines used a special mortar comprising sand from Mecca reinforced with the Prophet's saliva. See Matthews, "From the Fifteenth Century to the Present Day", 82.

Aydın, Pavilion of the Sacred Relics, 192. 


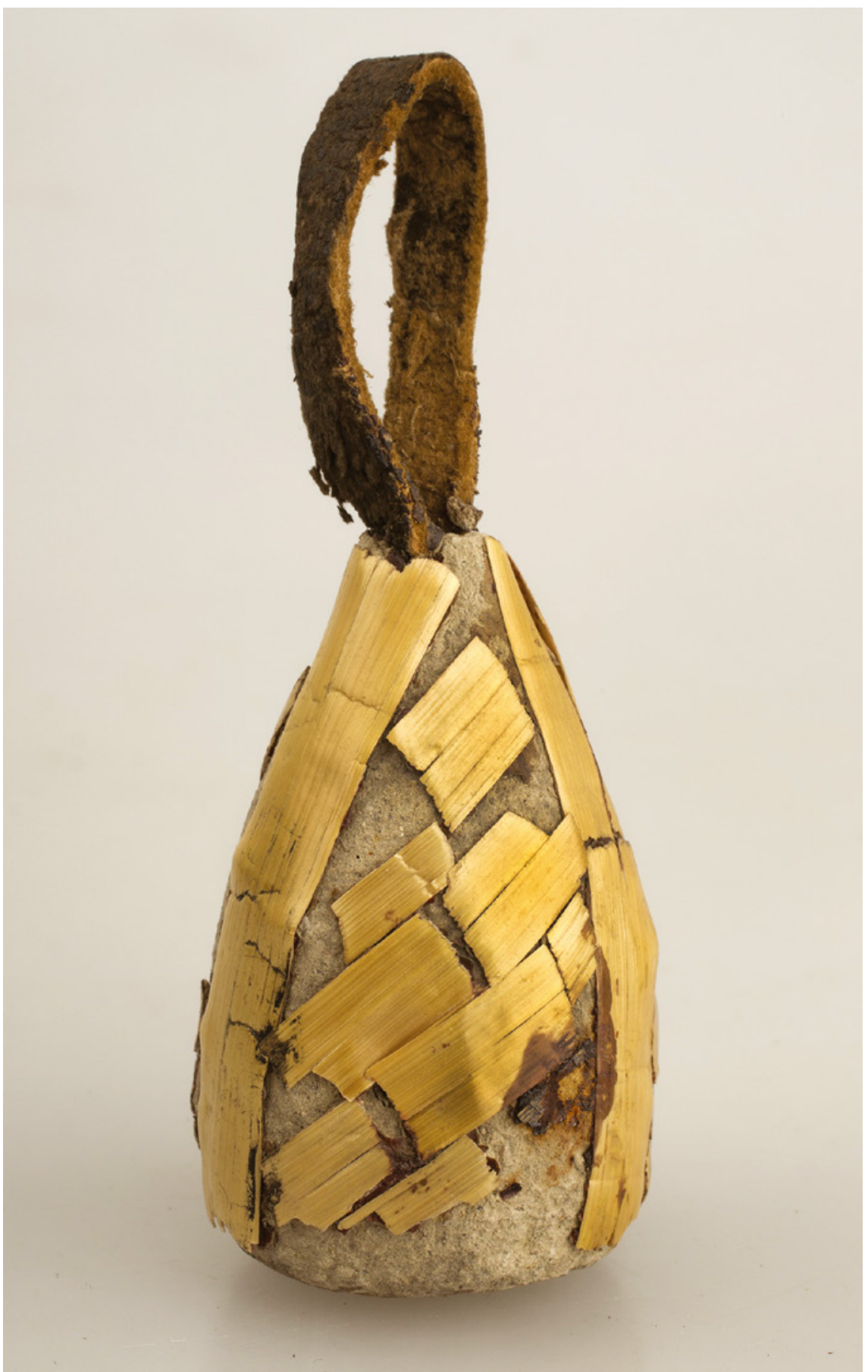

FIGURE 18.16 Conical straw bundle containing the soil from Medina, before 1958, Oosters Instituut (The Oriental Institute), Leiden, The Netherlands, RMV B106-49 
of outside of the tomb-mosque complex, where it was taken away by those waiting expressly for the purpose of collecting this blessed contact relic. ${ }^{34}$

In addition, many vessels were used to store the consecrated water of the Zamzam well in Mecca. Known as Zamzamiyyas, these flasks were made of both transparent glass and opaque porcelain, their necks often fastened shut with a rope or thread in a manner reminiscent of the hilye bottles (Figure 18.17). ${ }^{35}$ Textual records reveal that Zamzam water was poured on individuals' bodies and the shrouds of the deceased. Evliya Çelebi also specifically notes that the well's water was deemed useful to people suffering from gall bladder problems. ${ }^{36}$

The belief in the sacred and curative qualities of Zamzam water goes back to pre-Islamic times. ${ }^{37}$ During the Jāhiliya period, the Zamzam well was considered a sacred spring and home of the dead spirits. ${ }^{38}$ At the advent of Islam, the well was given new meaning as it intersected with the narrative of Hajar desperately seeking a water source to quench her and her son Ismāîl's thirst, when both were left to wander in the hot and arid Arabian desert. Since the water's miraculous appearance saved both mother and child from dying of dehydration, it has been considered a salvific substance granted as a blessing from God.

Still today Zamzam water bottles are offered for sale in Mecca as consecrated hajj souvenirs and gifts, ${ }^{39}$ and they also can be purchased from stores of devotional goods surrounding the Eyüp shrine in Istanbul (Figure 18.18). A religious twist on today's portable water bottles, these contemporary Zamzamiyyas underscore the tenacious belief in the healing powers of water, especially if touched by a holy relic or drawn from a sacred well. These vessels materially relate to and further sustain a substance often conceptualized as the "water of life" ( $\bar{a} b-\iota$ haya $\bar{t})$, itself a notion that pervades many world cultures and religions. Within Ottoman spheres, water vessels in general were thought as containers for this primal source of wellbeing; some such jugs therefore include inscriptions that encourage their owners to drink water in order to

34 Aydın, Pavilion of the Sacred Relics, 191.

35 On Zamzam bottles, see inter alia Aydın, Pavilion of the Sacred Relics, 197-98; Gök and Taşkın, Ab-ı hayat, 137, cat. no. 24; Gülsoy, Haremeyn: hac - mukaddese yolculuk, 302; Porter, "Gifts, Souvenirs, and the Hajj", 102, figure 5; Faroqhi, Travel and Artisans in the Ottoman Empire, 89f.; and Flood, "Bodies and Becoming," 472. On the item illustrated in figure 18.17, see Mols and Vrolijk, Western Arabia in the Leiden Collections, 70.

36 Faroqhi, Travel and Artisans in the Ottoman Empire, 89-9o.

37 On the Zamzam well, see Hawting, "The Disappearance and Rediscovery of Zamzam and the 'Well of the Ka'ba'.

38 Rubin, "The Ka'ba", noff.

39 On contemporary hajj souvenir flasks containing Zamzam water, see Khan, "Souvenirs and Gifts", 236f, figures 19 and 21. 


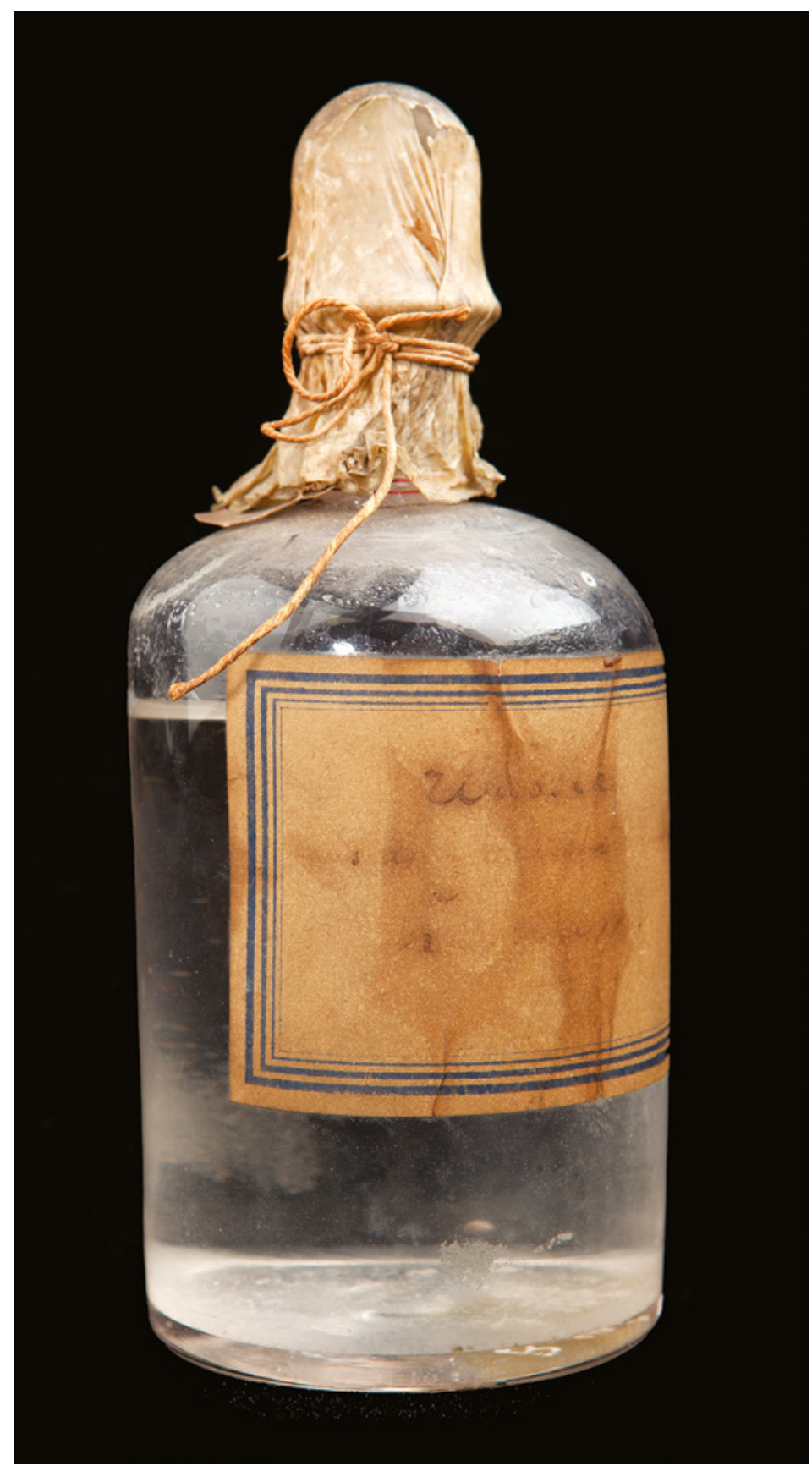

FIGURE 18.17 Glass bottle containing Zamzam water, before 1958, Oosters Instituut (The Oriental Institute), Leiden, The Netherlands, RMV B106-88 


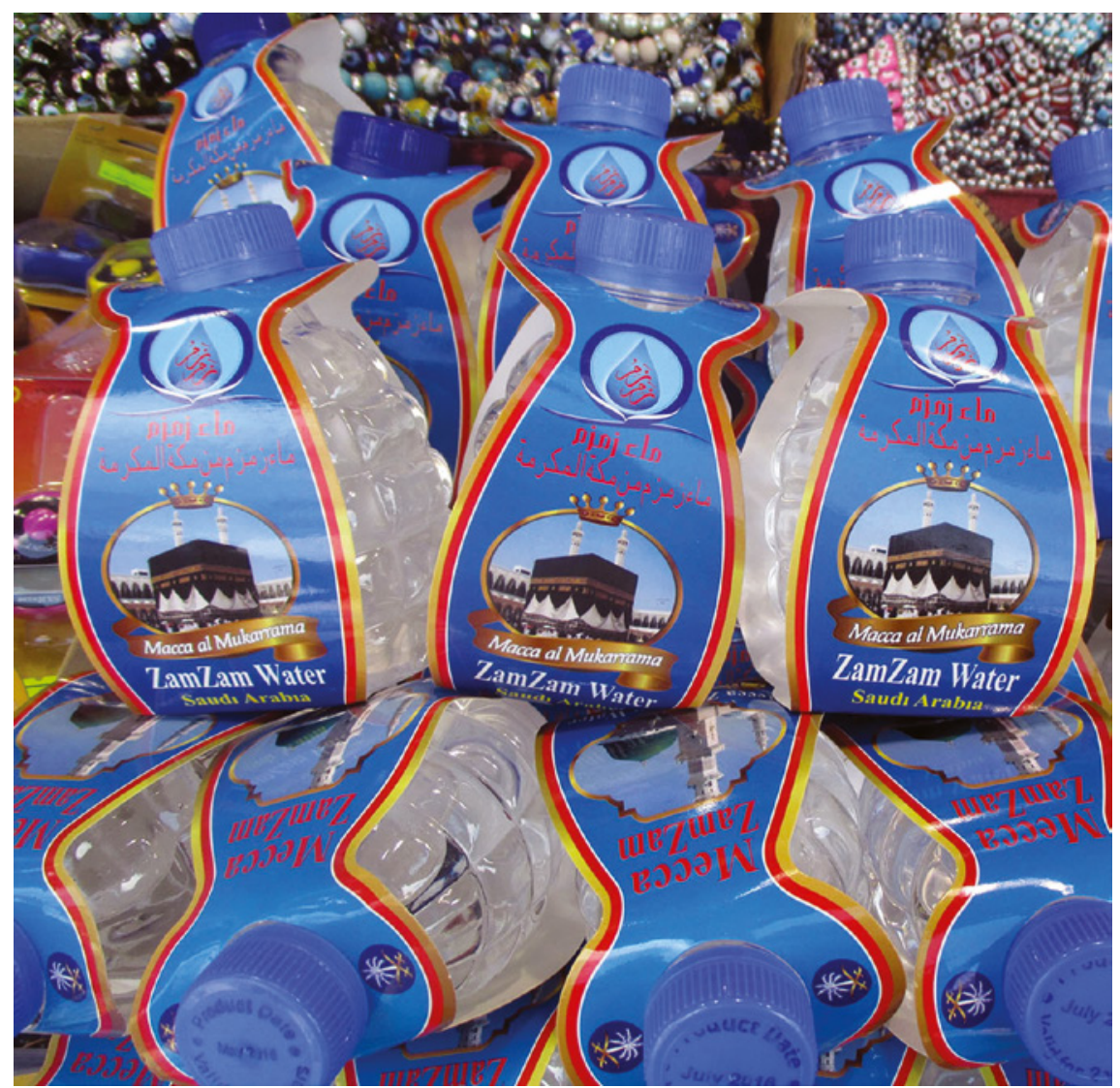

FIGURE 18.18 Plastic bottles filled with Zamzam water, offered for sale in a store of devotional goods near the Eyüp shrine, Istanbul PHOTOGRAPH BY AUTHOR, SUMMER 2016

find remedy.$^{40}$ Related to Zamzamiyyas and other $\bar{a} b$-ı hayāt vessels, hilye bottles expand this corpus of special flasks to promote the Prophet as the ultimate cure-all.

The devotee's possible drinking or ingestion of Prophetic baraka via a liquid or potion containing hilye gold dust might be argued by some as belonging to the realm of folk or popular belief. However, during Ottoman times this practice of seeking propinquity to - and even a physical fusing with - the Prophetic corpus could be conceptualized as meritorious and hence falling squarely within Sunnī traditions. Among the precedents that could validate the theological acceptability of such objects and their associated practices

40 Gök and Taşkın, Ab-ı hayat, 132. 
was the tradition of ingesting the Qurān. As Travis Zadeh has shown, blowing (nafth) verses of the Qurān over water and/or erasing (mahlw) them in water for ingestion by a person in ill health was considered a normative, salubrious, and divinely sanctioned practice since the emergence of Islam. ${ }^{41}$ As Zadeh stresses in this regard, "the very act of ingesting the trace of the written word dissolved in water represents a desire to draw the sacred power of the divine into the body."42

There existed a number of material ways to draw both the Qur'ān and the Prophet Muhammad into the flesh and body of the believer. While hilye bottles could tend to the task of the latter, a number of other vessels could fulfil the needs of the former. For example, besides the ample corpus of magico-medical bowls, ${ }^{43}$ which are well-known and studied, there also exist ceramic cups inscribed with Qur'annic verses. Such is the case for a nineteenthcentury Ottoman terracotta cup, whose interior walls are entirely covered with Sürat $Y \bar{a}-\operatorname{Sin}\left(Q_{3} 6\right)$, whose verses spiral from the cup's top rim to its base (Figure 18.19). ${ }^{44}$ Although intended for use in medicinal libation rituals, this exemplar's inscriptions remain in rather pristine condition, the water damage limited to a microscopic area of the vessel.

Considered one of the most apotropaic chapters of the Quraan, Yā-Sin is often found on amulets and talismans. ${ }^{45}$ However, when inscribed within a cup, the verses most likely were destined for erasure (mahw $)$ in water. A number of Islamic textual sources support this practice: for example, one hadith records the Prophet Muhammad relating the following about Yā-Sinn: "Whoever writes it and then drinks it, the süra puts inside his belly a thousand remedies." 46 Building upon this hadìth, the early Sunnī theologian Ibn Hanbal (d. 241/855) goes further, declaring that "a man without a bit of the Qur'àn in his belly is like a broken-down house." 4

Much as believers were in the habit of drinking the word of God, it appears that they also wished to put a little bit of the Prophet in their belly as well. Late Ottoman Qurān and hilye bottles appear to have facilitated such acts

41 Zadeh, "An Ingestible Scripture", 101 and 1o9; and idem, "Touching and Ingesting", 464.

42 Zadeh, "Touching and Ingesting," 466.

43 On magico-medicinal bowls, see in particular Perk and Paksoy, Duanın Sudaki Gizemi Sifa Tasları, 11, 108, 118, 134-135, and 139; Savage-Smith, Science, Tools \& Magic, part 1, 72-97; Ittig, "A Talismanic Bowl", 79-94; and Spoer, "Arabic Magic Medicinal Bowls", 477-80.

44 This cup is published in Tanman, Ekrem Hakkı Ayverdi, 1899-1984, 268, cat. no. 120.

45 On the inclusion of $Y \bar{a}-\operatorname{Sin}$ and other Qurānic chapters and verses in Islamic amulets, see Leoni, "Sacred Words, Sacred Power", 53-65.

46 Zadeh, "An Ingestible Scripture," 108 (cited in Mustaghfirīs [d. 432/1041] compendium of hadìth).

47 Ibid. 


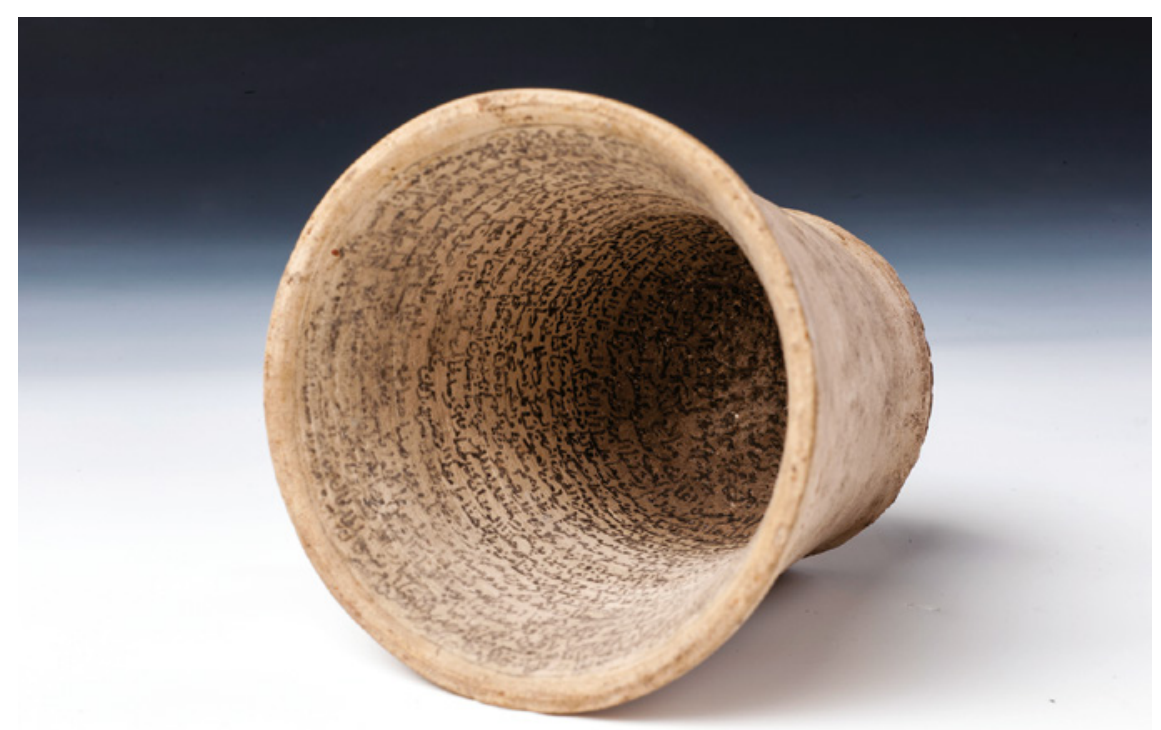

FIGURE 18.19 Terracotta cup inscribed with Sūrat Yā-Sīn, Ottoman lands, 19th century. Ekrem Hakkı Ayverdi Collection, Istanbul, cat. no. 120

of corporeal actuation and animation by establishing a material merging between holy scripture, the Prophet Muhammad, and the believer's body. As Finbarr Barry Flood notes in this regard: "Whether the object of desire is the baraka emanating from prophet, saint, or logos, the ingestion of the sacred has as its ultimate end not a mimetic imitation of the sacred but a merging of the self with it." 48 Late Ottoman hilye bottles and related vessels suggest that one of the "means of merging" with the Prophetic corpus included rituals of rocking verbal icons, pulverizing gold pigment, and creating a sacred substance meant for ingestion and absorption in the human body at a near cellular level. This conceptualization of water and word as especially powerful appear in Byzantine traditions as well. ${ }^{49}$

\section{Christian Holy Springs and Curative Icon-Bottles}

Hilye bottles formed part of the larger lifeworld of Istanbul during the nineteenth and early twentieth centuries, at which time late Ottoman-Islamic

48 Flood, "Bodies and Becoming," 483.

49 Nilsson, "Words, Water, and Power". 
devotions to the Prophet Muhammad appear to have coincided with the cult of healing waters shared by the city's Christian and Muslim dwellers. The belief in water's sacred and curative powers can be traced back much further in time to the numerous ancient Near Eastern holy springs, lakes, and caves spread across the Mediterranean Basin and Anatolian plateau. ${ }^{50}$ Sacred water sources became central to Christianity as well, as attested to by the rite of baptism, baptismal fonts, and the spread of holy springs associated with churches and chapels. In Greek, such springs are known as "holy water," or hagiasma (plural, hagiasmata), and they are founded in the memory of Christ's baptism or dedicated to a particular saint. At one time, Istanbul counted more than two hundred such springs; unfortunately, today most have disappeared under road, rail, and building construction. ${ }^{51}$

After the conquest of the city by Ottoman forces in 1453, the growing local Muslim population also came to consider such springs miraculous and therapeutic ${ }^{52}$ - the belief in sacred water in Islam stretching back to the earliest narratives about the Zamzam well having saved Hajar and Ismāîl from death. In Ottoman and modern Turkish, these springs are known as ayazmas, a term etymologically indebted to the Byzantine Christian hagiasmas in the city. Still today, a number of ayazmas in Istanbul are in operation and remain quite popular. Once a week, and on feast days and special occasions, they host visitors of all faiths and nationalities who come to these sacred water sites in order to make wishes, seek blessings, or ask for healing via the practices of visitation, prayer, and votive donation. These ayazmas are filled with decorated icons and bottles containing images of the Virgin Mary and Jesus Christ. Most germane to the theme at hand, some bottles are filled or impressed with an icon of Mary and/or Christ, revealing the extent to which hilye bottles appear indebted to Constantinopolitan Christian and Islamic sacred spring traditions and their associated devotional objects.

Today, a number of ayazmas host Christian and Muslim pilgrims as well as visitors of all religious persuasions and none. The most important of these are: The Virgin as "Fountain of Life" (Zoodochos Pege) sacred spring and church in Balıkli; The St. Demetrios shrine and spring in Kuruçeşme; the "curing" (Panagia) spring located within the "First of the Month" (Ayın Biri) Church in Unkapanı; St. Catherine's holy spring in Moda; and the St. George Monastery in

50 See in particular Harmanşah, Of Rocks and Water.

51 Değer, İstanbul'un şifalı suları, 126.

52 On the Muslim visitation of Christian sanctuaries during late Ottoman times, see Hasluck, Christianity and Islam under the Sultans, vol. 1, 63-74. 
Büyükada, the largest of the Prince's Islands. ${ }^{53}$ At each site, a number of devotional and votive traditions continue to flourish today, offering contemporary ethnographic evidence that can help shed some light on previous holy spring traditions. These springs likewise may illuminate the symbolic uses and meanings of icon-bottles in both Christian and Muslim spheres.

The oldest, most important, and best known hagiasma in Istanbul is that of the Virgin as the "Fountain of Life" or "Life-Giving Source" (Zoodochos Pege). This church-spring complex was founded close to the city's defensive walls in the fifth or sixth centuries, either by the Byzantine emperor Leo I (r. 457-74) or Justinian (r. 527-65). ${ }^{54}$ Textual sources inform us that the church-spring effectuated 47 miracles and cures between the years $45^{\circ}$ and 950. ${ }^{55}$ During the Ottoman period, the church was destroyed and rebuilt several times, at which time a story about a fried fish (balık) miraculously returning to life after jumping in its spring waters endowed the hagiasma with its present Turkish name, "The Fish [Spring]" (Balıkl). ${ }^{56}$ The site was particularly active during the nineteenth century, at which time its church, chapel, and crypt were fully rebuilt and inaugurated in 1835 after its destruction during the Greek Revolution in $1821 .{ }^{57}$ In the wake of its reconsecration, the complex was visited by the Ottoman Sultan Mahmud II (r. 1808-39), ${ }^{58}$ who extended financial support and showed respect to various Christian churches, their holy springs, and religious ceremonies..$^{59}$

Around this time, an image made by Thomas Allom and published in Robert Walsh's 1838 travel narrative to Constantinople depicts this so-called "Spring of the Miraculous Fishes at Baloukli" populated by various visitors, some of whom dip their feet into the holy spring or use vessels to drink its curative waters (Figure 18.20). ${ }^{60}$

53 For the most detailed discussion of the city's Christian hagiasmata, see Atzemoglou, T'hagiasmata tēs Polēs. The author wishes to thank George Manginis for translating key portions of this Greek-language publication.

Narratives relate a story of Leo I and a blind man, as well as Justinian seeking a cure for a urinary tract infection. See Talbot, "Holy Springs and Pools in Byzantine Constantinople", 164ff. For further information on the Zoodochos Pege complex, see Atzemoglou, T'hagiasmata tēs Polēs, 64-67; Değer, İstanbul'un şifalı suları, 100-106; and idem, "Holy Springs," 12gff. Further references follow below.

55 Kimmelfield, "The Shrine of the Theotokos at the Pege", 300.

56 Kimmelfield, "The Shrine of the Theotokos at the Pege", 308.

57 Talbot, "Holy Springs and Pools in Byzantine Constantinople", 172.

58 Atzemoglou, T'hagiasmata tēs Polēs, 67.

59 Sultan Mahmud II will be discussed subsequently.

6o Walsh, Constantinople and the Scenery of the Seven Churches of Asia Minor, plate located between pages $5^{0}-51$. 


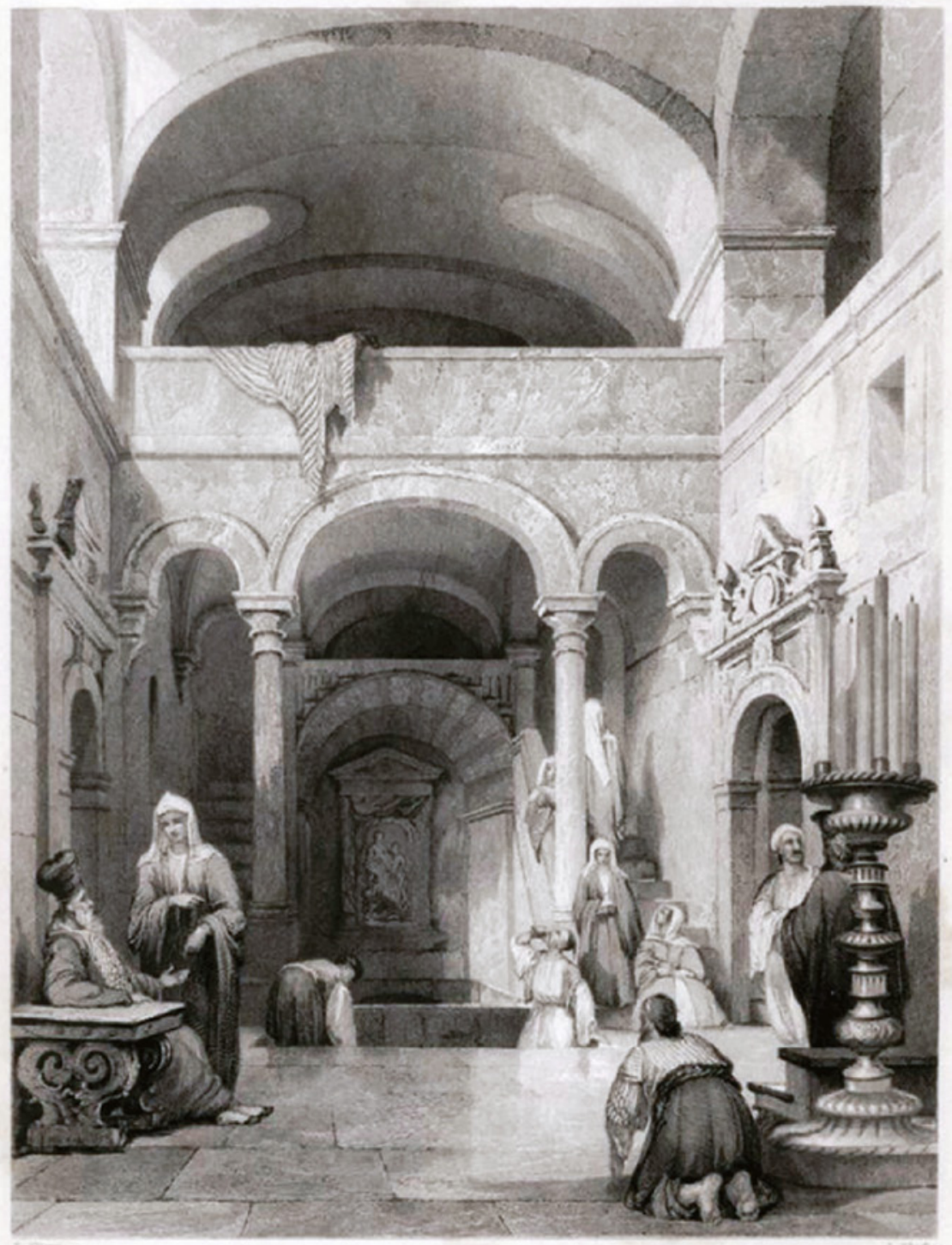

FIGURE 18.20 "Spring of the Miraculous Fishes at Baloukli," included in Robert Walsh, Constantinople and the Scenery of the Seven Churches of Asia Minor Illustrated in a Series of Drawings from Nature by Thomas Allom (London and Paris: Fisher, 1838 ), pages $5^{0}-5^{1}$ 
As Walsh relates in his text, this lively spring was visited by both "Greeks" and "Turks." At the water source, he continues:

Priests stood around the Spring with pitchers in their hands, which they constantly filled, and handed up to those close to them. They were eagerly seized by every person who could catch them, and poured with trembling emotion on their heads and breasts, where they were rubbed, so that every particle of the life-giving fluid might be imbibed by the pores of the skin. ${ }^{61}$

Today, the Balıklı spring retains some of its most salient features, including an icon of the Virgin Mary and Christ Child located immediately above the sacred waters (Figure 18.21). The silver-encrusted wall painting above the water depicts Mary as a life-giving spring, as she bursts forth out of a source of water, from which Christian priests, warriors, and devotees seek relief and cure. ${ }^{62}$ Moreover, in its foreground, a man in a red robe is shown holding a vessel and pouring the spring's sacred water into the eyes of a man most likely suffering from ophthalmological problems - a depiction that is befitting for this hagiasma since its foundation story includes a miraculous cure for blindness.

Although today the image appears as a wall painting, Byzantine sources describe a mosaic icon of the Virgin Mary instead. This mosaic, we are told, reflected in the spring's water, making it seem as if the image were incubating within it and thus endowing it with life. As Robert Ousterhout notes, it must have been difficult for visitors to differentiate the mosaic depiction from its aquatic reflection, so "perhaps it is best to say that the two - the image and the water, the icon and the substance - worked in concert." ${ }^{33}$ Filled with the figural image of a saintly figure as well as charged with its healing powers, this new holy amalgam yielded what might be best called "icon water."

While the icon water of the Zoodochos Pege spring was most likely collected and distributed in metal jugs and glass vessels in previous centuries, today's visitors - Christian, Muslim, and other - are encouraged to make a monetary donation in exchange for a plastic bottle, into which they gather the consecrated substance. Many cheap and mass-produced bottles line one of the walls in the spring's crypt, waiting to be put to good use. Of hand-held size and thus highly portable, each bottle identifies the hagiasma by name in an oval

\footnotetext{
$61 \quad$ Ibid, 52.

62 On depictions of the Virgin Mary as a "Life-Giving Source," see Teteriatnikov, "The Image of the Virgin Zoodochos Pege", 225-33.

63 Ousterhout, "Water and Healing in Constantinople", 73.
} 


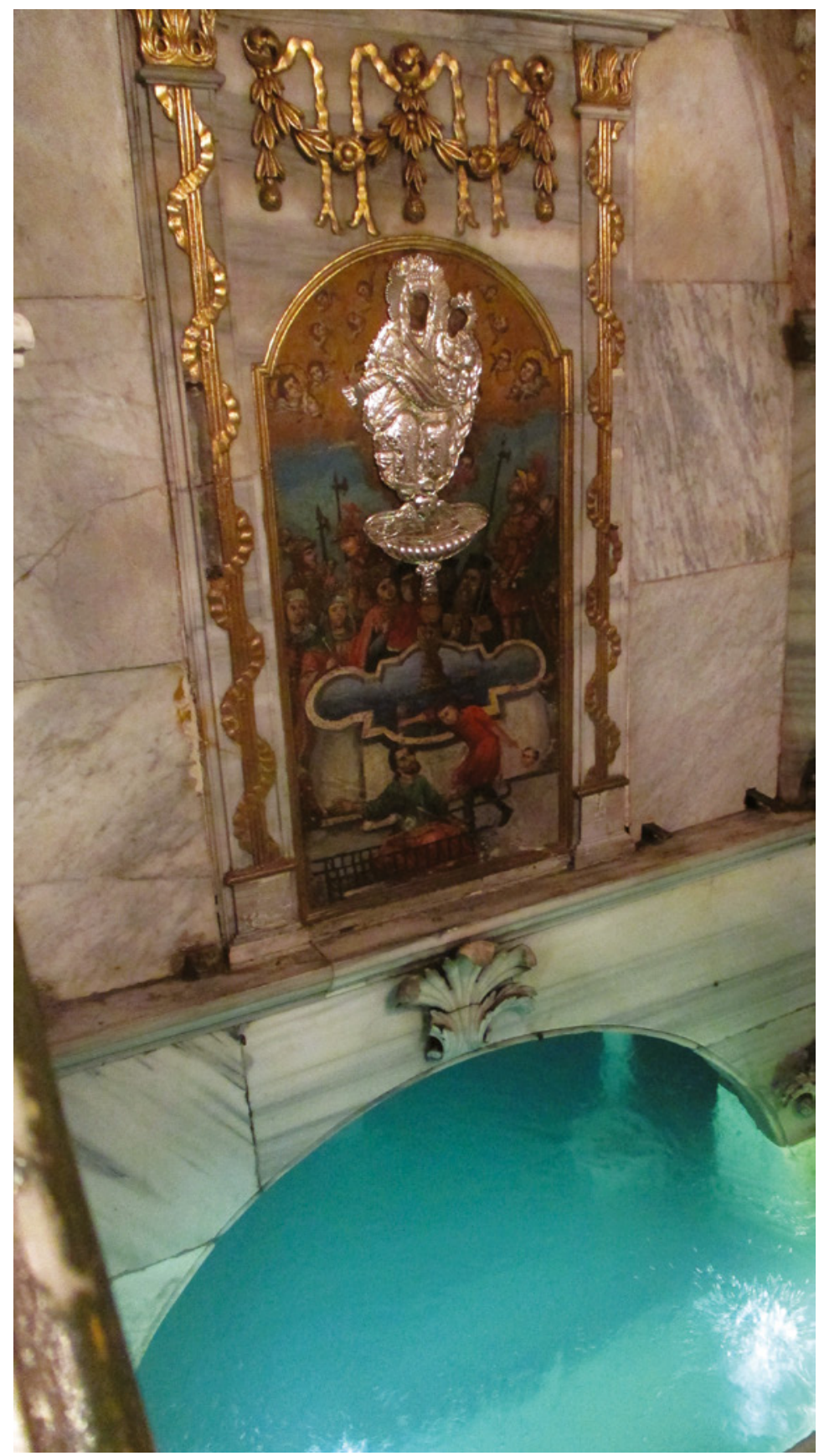

FIGURE 18.21 The sacred spring and icon of the Virgin Mary and Christ Child in the "Fountain of Life" (Zoodochos Pege) crypt church in

Balıklı, Istanbul

PHOTOGRAPH BY AUTHOR, SUMMER 2018 
that frames an icon of Mary and Christ emerging from the "fountain of life" (Figure 18.22). This icon impressed upon the translucent body of the plastic container generates a similar effect to the mosaic image reflected within the sacred spring: that is, it appears that the image is incubating within the water or, alternatively, that the icon is coming to life with every ripple of the liquid. These holy souvenirs are then taken away and imbibed by individuals seeking remedy or relief - their disparate faiths and worldviews united in the universal belief in water's healing powers.

Centuries-old thalassotherapeutic traditions include bathing in springs, lakes, and seas, as well as mud cures. Within a Mediterranean context they are best attested by the Asklepion, a famous Roman medical centre located in Pergamon. Built in honour of Asklepios, the Roman god of healing, during the second century, the Asklepion included a number of spa-like cures based on a local sacred water source, which has been shown to contain particularly curative properties. Water treatments, mud baths, and the drinking of water counted among its medical treatments; such remedies then carried over to Christian sacred springs, especially those located in close proximity to water and sand. During the Ottoman period, hydrotherapy was similarly practiced at the famous Ottoman hospital in Edirne, which also included music therapy.

Within Constantinople, one hagiasma that included water and mud cures was the spring of St. Saviour Philanthropos, located in the St. George monastery complex. The structure was built in the twelfth century between the sea and the city's maritime walls (Figure 18.23). Because of its particular location, it was referred to as the "ayazma of the rampart" (ayazma de la muraille) by French travellers, including Joseph Pitton de Tournefort (d. 1708). Around 1700, de Tournefort recorded the Ottoman Sultan's visit to the sacred spring and his observing of its mud cures during the Feast of Transfiguration, noting: ${ }^{64}$

They [the Greeks] believe that this water cures fever and also the gravest sickness, both present and future. It is for this reason that they both bring the ill to [this holy spring] to have them drink [of its waters] and also bury them into the sand up to their necks, exhuming them immediately thereafter.

64 De Tournefort cited in Demangel and Mamboury, "Le monastère et l'ayasma du SaintSauveur", 62, fn 6: Non seulement ils croient que cette eau guérit la fièvre, mais encore les maladies les plus fâcheuses tant présentes que futures. C'est pour cela qu'ils ne se contentent pas d'y amener les malades pour les faire boire; ils les enterrent dans le sable jusques au col et les déterrent un moment après. 


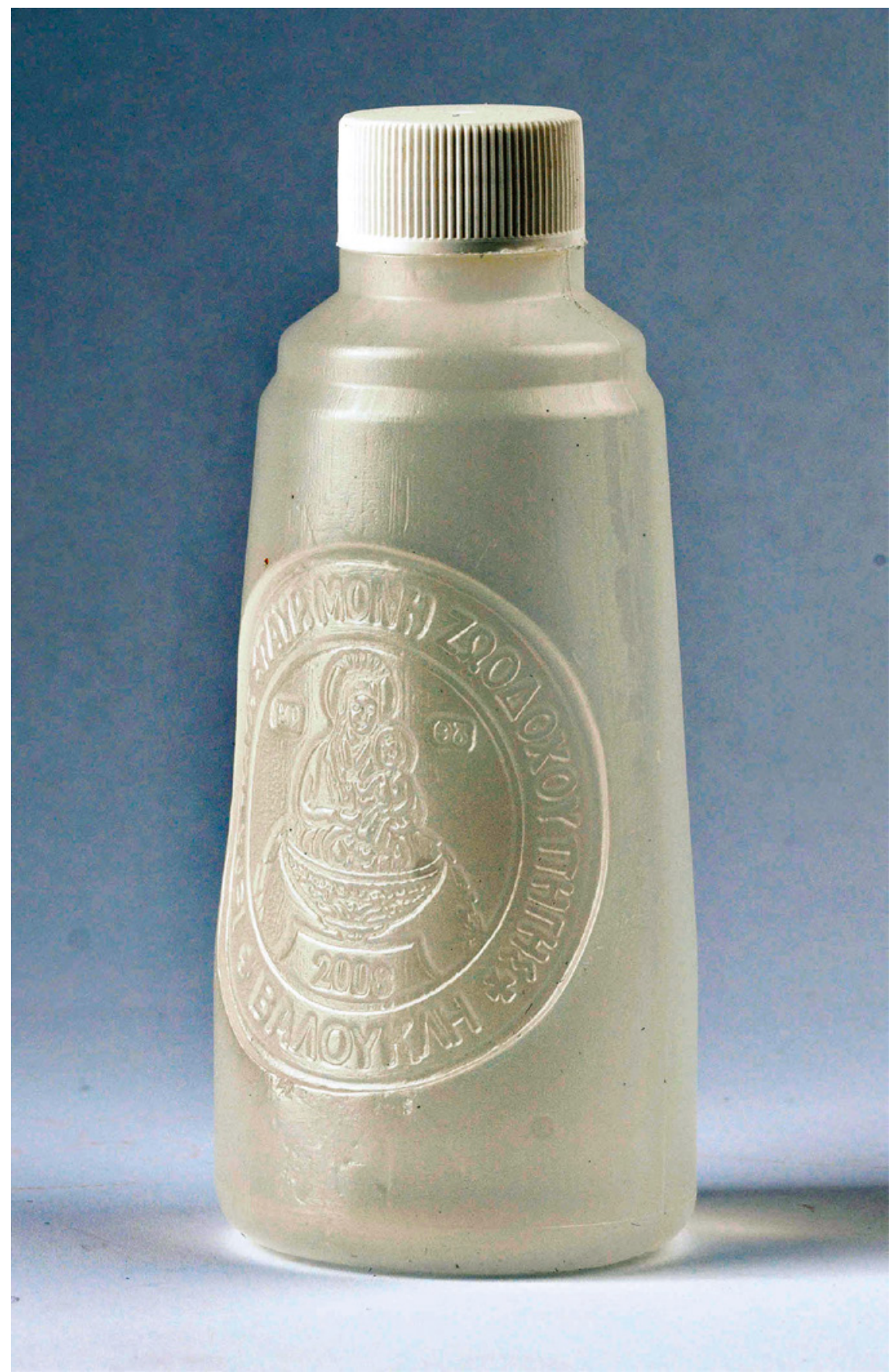

FIGURE 18.22 Plastic water bottle impressed with the name of the Zoodochos Pege sacred spring and an image depicting the Virgin Mary and Christ Child. Bottle acquired at the holy spring by the author in summer 2018 


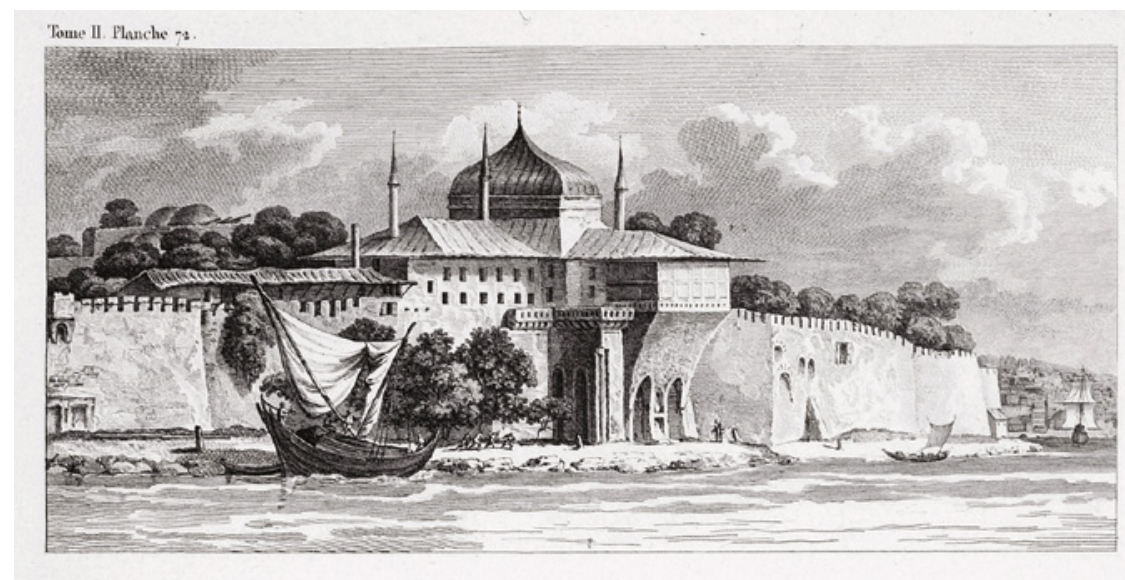

Vue d'Indjuuli-Kiosk

FIGURE 18.23 "Vue d'Indjiuli-Kiosk," image included in Choiseul-Gouffier, Voyage pittoresque dans l'Empire ottoman, en Grèce, dans la Troade, les îles de l'Archipel et sur les côtes de l'Asie-mineure (Paris: J.-P. Aillaud, 1842), volume 2, plate 72

Located in the Mangana/Sarayburnu area of Constantinople, this "ayazma of the rampart" was in fact located on the grounds of Topkapı Palace during Ottoman times; hence, it was in close proximity to the seat of power and the royal library, where the hilye bottles are preserved today.

Textual sources inform us that several Ottoman rulers visited this spring, to which they added a Turkish fountain in the sixteenth century. ${ }^{65}$ Thereafter, the ayazma became known as the "Pearl Pavilion" (İncili Köşk) and the "Pavilion of the Garden Superintendent" (Bostancıbaşı Köşkü). During the nineteenth century, Christians visited the spring, even though it was on palace grounds. ${ }^{66}$ Likewise, Sultan Mahmud II showed great respect to the church and holy spring of St. Saviour Philanthropos: in 1816, for example, he supported its Feast of Transfiguration, which included a number of mud cures performed on the seaside. ${ }^{67}$ Unfortunately, it is now impossible to know whether this "royal ayazma" included icon-bottles as it was raised to the ground in 1871 in order to make way for the construction of a new railroad. ${ }^{68}$

65 Water fountains proliferated in Istanbul from the sixteenth century onward; indeed, during the eighteenth century, at least 365 Ottoman fountains were built. See Hamadeh, "Splash and Spectacle", 123-48.

66 Ousterhout, "Water and Healing in Constantinople", 71-72.

67 Demangel and Mamboury, "Le monastère et l'ayasma du Saint-Sauveur", 57.

68 Demangel and Mamboury, "Le monastère et l'ayasma du Saint-Sauveur", 56. 
Other surviving Christian icon-bottles associated with monasteries, churches, and sacred springs both within and beyond Turkey suggest that these types of religious wares would have been readily available to both Christian and Muslim individuals. Within Turkey, local Greek inhabitants owned their own sacred water bottles, at times having brought back such items from pilgrimages abroad. For example, one undated bottle displays icons of the Virgin Mary and Christ Child with Saint Eleutherios (the patron saint of pregnant women) on one side of its icon panel, while its other side depicts the Annunciation and Saint George (Figure 18.24). Tucked between the two latter scenes appears a representation of the monastery of the Virgin Evangelistria (of the Annunciation) on Tenos, one of Greece's Cyclades islands. This sacred architectural complex includes the Church of the "Virgin Mary With All Graces" (Panagia Megalochari), which is dedicated to the Annunciation. As one of the foremost Christian pilgrimage sites in Greece, the church includes a miraculous icon of Mary, which was "discovered" in 1823 and now is placed over an hagiasma.

This bottle was most likely acquired in the nineteenth or early twentieth century by a Christian Istanbulite, who wished to own a keepsake from his or her pilgrimage to the miraculous icon as well as to bring the blessings associated with its nearby water source back home. This icon bottle thus continues and adapts the centuries-old production of Christian pilgrimage flasks. More to the point, this Christian icon-vessel recalls the first hilye bottle (see Figures 18.2 and 18.3), which similarly is sealed shut, displays architectural representations of pilgrimage sites, and includes a number of ornaments, such as wicker branches and plastic beads. In the exemplar from Tinos, however, such decorations include glitter and dried flowers, which have fallen off the icon and deteriorated into dust at the base of the object.

Other Christian icon-bottles appear as a diminutive form of installation art. For example, one item made in Hungary is now on display in the museum of the Bachkovo Monastery in Bulgaria (Figure 18.25). ${ }^{69}$ Sealed shut, the bottle's interior includes a small-scale sculpture showing the crucifixion of Jesus Christ, around which are placed a number of objects associated with his passion. Known collectively as the Arma Christi (Weapons of Christ), these instruments were used to torment Christ before his death and include nails, the Crown of Thorns, and the Spear of Longinus, among others. ${ }^{70}$ In addition, much like the Tinos complex, the Bachkovo Monastery preserves a holy icon to which today's Christian visitors perform pilgrimage and make pious entreaties, including for increased good health.

69 For further information about the site, see Kissyov, Bachkovo Monastery.

70 For a general discussion of the Arma Christi, see Cooper and Denny-Brown, The Arma Christi in Medieval and Early Modern Material Culture. 


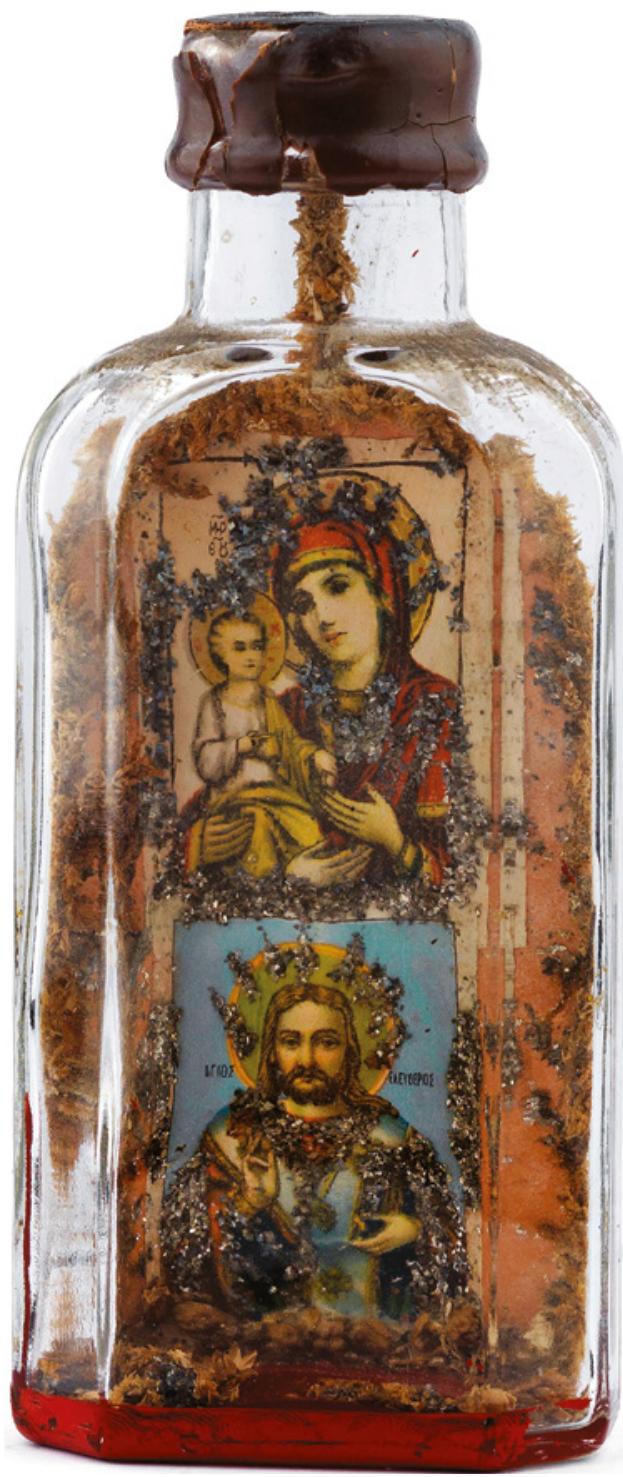

FIGURE 18.24

Icon bottle showing the Virgin Mary and Christ Child with Saint Eleutherios, Monastery of the Virgin Evangelistria, Tenos, Greece, 19th or 2 oth century. Bottle acquired in Istanbul by the author in summer 2017

As for Istanbul's ayazmas, today they are visited by thousands of Christians and Muslims on their respective feast days, as is the case for 2 July celebrations at the Ayvansaray holy spring. ${ }^{71}$ Moreover, the keeper of the church at St. George Monastery in Büyükada is a Muslim woman, who informs visitors

71 Değer, Istanbul'un şifalı suları, 130-32; and idem, "Holy Springs," 143-44. Shared Christian and Muslim pilgrimage and water rituals also take place in Lebanon; see Farra-Haddad, "Shared Rituals through ziyarat in Lebanon", especially p. 46 on water rituals. 


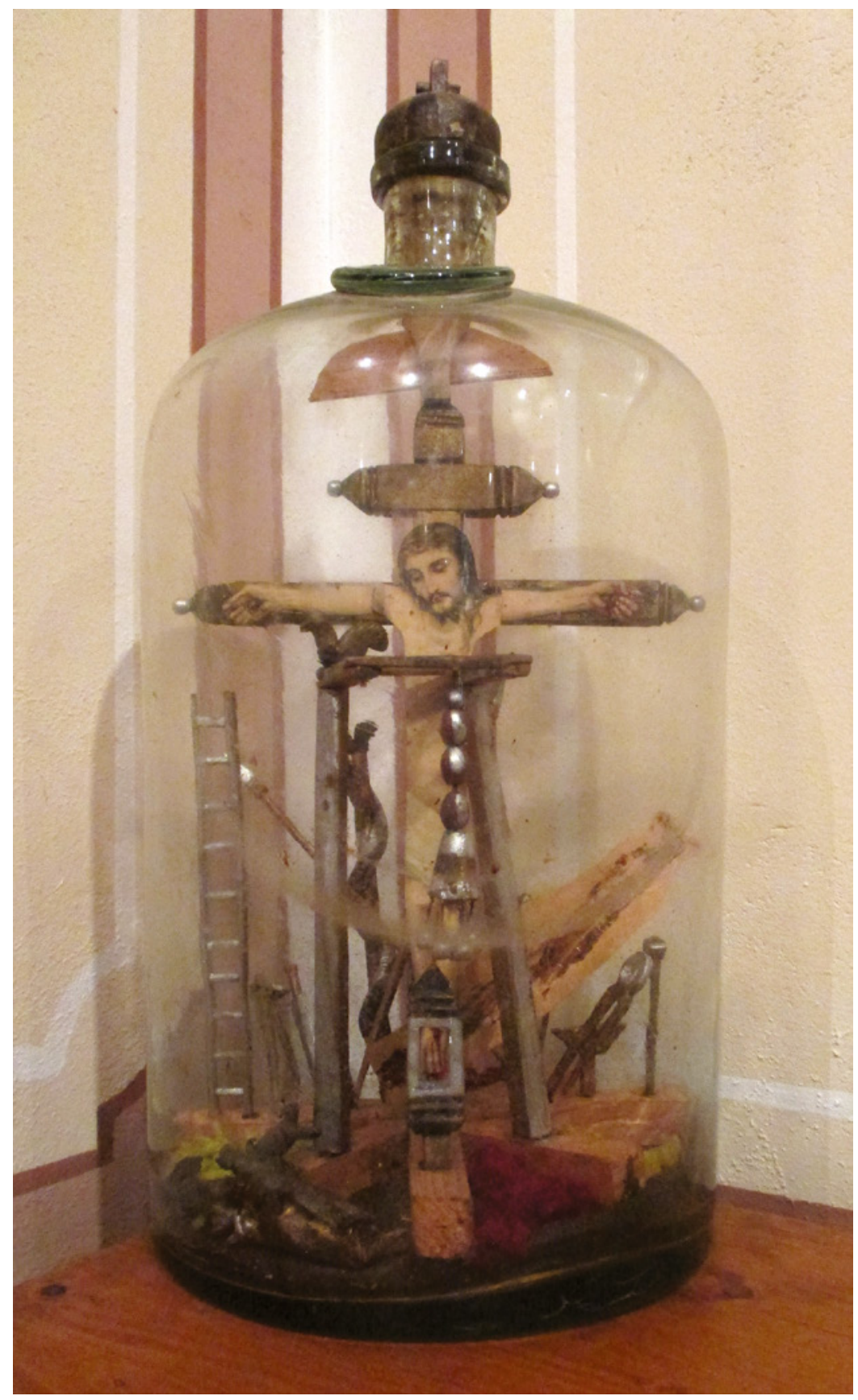

FIGURE 18.25 Icon bottle depicting the Passion of Christ, made in Hungary, nineteenth or twentieth century. Bachkovo Monastery Museum, Bulgaria PHOTOGRAPH BY AUTHOR, SUMMER 2018 
that Saint George is equated to Khidrr, the Muslim saint who is said to have discovered the spring of life. ${ }^{72}$ Moving to the Anatolian side of Istanbul, the ayazma of Saint Catherine in Moda also hosts Muslim pilgrims, including one woman who is recorded as having visited the site in order to break a spell cast upon her. ${ }^{73}$ Moving up the Bosphorus, visitors to the St. Demetrios shrine walk through an underground passage to its sacred spring, which is believed to be effective in helping children overcome speech disorders. This passage includes a ceiling and walls from which water drips down. As they proceed forward, visitors of all stripes take the liberty to inscribe graffiti along the walls, some of which issue the following requests: "I wish my in-laws did not interfere with my life," "I wish to lose weight without losing my health," "I wish to get married soon," and "I wish to become a house owner." ${ }^{4}$ Last but not least, during two summer 2017 visits to the ayazma of the "First of the Month" (Ayin Biri) Church in Unkapanı, I myself witnessed Christian and Muslim women symbolically opening Christian icons with small metal keys prior to collecting the spring's holy water in purpose-made plastic bottles. A Muslim visitor's unlocking of a Christian icon's power and her collecting of this Christian spring's sacred water prove especially noteworthy when one considers both the origins and functions of late Ottoman hilye bottles.

As a result, the Christian belief in the therapeutic power of holy spring and icon water appears to have carried over into Ottoman Muslim beliefs and practices, which, to a certain extent, still remain visible in Istanbul's ayazmas of today. The cult of water in the city (and across the region) goes back centuries; however, during the nineteenth century, encounters between Christians and Muslims, including at their shared sacred springs, must have prompted an increased exchange in symbolic objects as well, especially after the eighteenth century. Among them can be counted Christian icon-bottles, which may have catalysed hilye bottles - the latter transforming a figural icon of Christ into a verbal depiction of Muhammad. Whether catering to the Christian or Muslim faith, these types of curative icon-bottles are nevertheless united in their indebtedness to age-old hydrotherapeutic traditions, to which they creatively added new twists.

72 Değer, Istanbul'un şifalı suları, 133.

73 Değer, "Holy Springs", 138.

74 Değer, "Holy Springs", 132. 
Based on a close analysis of these newly discovered hilye bottles, related Ottoman icons and paintings, vessels for Zamzam water, and Constantinopolitan holy spring culture and objects, it appears likely that Islamic icon-bottles essentially provided a new type of Prophetic pharmacon in Ottoman quarters, including royal ones, during the late nineteenth century in particular. At this time, the Prophet's verbal icon transformed from an amuletic object of visual meditation to an encased relic, whose golden by-product was most likely mixed into medicinal paste or Zamzam water destined to be ingested and therefore alloyed with the body of the faithful. Like the famous Meccan well, the Prophet therefore could symbolically function as a spring, or 'ayn, of belief and cure.

While other hilye bottles remain to be studied in greater detail, it nevertheless seems that these objects were quite rare and linked to an Ottoman palace milieu. If two of them were indeed used for the production of gold powder, this powder may have been blended into the "red paste," which an archival document of the late eighteenth century notes as exclusively reserved for the sultan. In such a case, these objects should be considered royal products, and their use and inspiration may have been connected to the seaside "Pearl Pavilion" spring that was located on palace grounds.

In the end, hilye bottles facilitated a number of pious engagements with a "Bottled Prophet" of sorts. Such engagements involved multiple senses, especially sight, touch, and taste as well as various "rituals of incorporation,"75 which may have included feast-specific prayers and libations. Late Ottoman multisensorial practices that involved the consumption of Prophetic baraka thus heralded a new turn in Muhammad-centred devotional products as these intersected with medicinal practices in elite spheres. Like other healing tonics, these products essentially provided a new kind of Prophetic antidote, promising a cure for illness and a long life. They also reasserted Muhammad's supreme standing as a wellspring of belief and the ultimate healing agent ready to be primed, gathered, absorbed, and thus fully embodied by his pious followers.

\section{Acknowledgements}

The author wishes to thank Zeynep Çelik Atbaş for bringing these bottles to her attention and for facilitating research in the Topkapı Palace Library. Thanks also are due to Önder Özsoy for shooting high-resolution photographs of the bottles. 


\section{Bibliography}

\section{Secondary Literature}

Alif Art: Osmanlı ve Karma Sanat Eserleri Müzayedesi, Ortaköy, Istanbul, March 9, 2014. Aşk-ı Nebi: Doğumunun 1443. Ylında Hz. Peygamber / Love for the Prophet: The Prophet Muhammad on the 1443th Anniversary of his Birth, Istanbul, Kültür Sanat Basımevi, 2014.

Atzemoglou, N. T'hagiasmata tēs Polēs [The Holy Water Springs of Constantinople], Athens, Rēsos, 199o.

Aydın, H. Pavilion of the Sacred Relics: The Sacred Trusts, Topkapi Palace Museum, Istanbul, Istanbul, The Light, Inc. 2004.

Başlangıcından günümüze kadar büyük Türk klâsikleri: tarih, antoloji, ansiklopedi, Istanbul, Ötüken, 1985 .

Bilgi, H. Gönülden Bir Tutku: Sevgi Gönül Hat Koleksiyonu / A Heartfelt Passion: The Sevgi Gönül Calligraphy Collection, Istanbul, Vehbi Koç Foundation, 2004.

Çağman, F. Kat'l: Cut Paper Works and Artists in the Ottoman World, Istanbul, Aygaz, 2014.

Chekhab-Abudaya, M. Desvergnes, A. C. and Roxburgh, D. "Sayyid Yusuf's 1433 Pilgrimage Scroll (Ziyaratnama) in the Collection of the Museum of Islamic Art, Doha", Muqarnas 33 (2016), 345-407.

Cooper, L. and Denny-Brown, A., eds. The Arma Christi in Medieval and Early Modern Material Culture, Farnham, Surrey, Ashgate, 2014.

Dawkins, J. M. "The Seal of Solomon", Journal of the Royal Asiatic Society (October 1944), 145-150.

Değer, M. İstanbul'un şifalı suları / The Healing Waters of Istanbul, Istanbul, European Capital of Culture Agency, 2010.

Değer, M. "Holy Springs", in E. Kalkan, ed. The World Beneath Istanbul, Istanbul, İstanbul Büyükşehir Belediyesi, 2010, 126-151.

Demangel, R. and Mamboury, E. "Le monastère et l'ayasma du Saint-Sauveur", in R. Demangel, and E. Mamboury, Le quartier des Manganes et la première région de Constantinople, Paris, E. de Boccard, 1939, 50-68.

Elgood, C. "Tibb-ul-Nabi or Medicine of the Prophet", Osiris 14 (1962), 33-192.

Faroqhi, S. Travel and Artisans in the Ottoman Empire: Employment and Mobility in the Early Modern Era, London and New York, I.B. Tauris, 2014.

Farra-Haddad, N. "Shared Rituals through ziyarat in Lebanon: A Typology of Christian and Muslim Practices", in I. Weinrich, ed. Performing Religion:Actors, Contexts, and Texts. Case Studies on Islam, Würzburg, Ergon Verlag, 2016, 37-51.

Flood, F. B. Technologies de dévotion dans les arts de l'Islam: Pèlerins, reliques et copies, Paris, Musée du Louvre and Éditions Hazan, 2019. 
Flood, F. B. "Bodies and Becoming: Mimesis, Mediation, and the Ingestion of the Sacred in Christianity and Islam", in S. Promey, ed. Sensational Religion: Sensory Cultures in Material Practice, New Haven and London, Yale University Press, 2014, 459-93.

Gemici, N. "Mecca in the Seyahatnâme", in R. Dankoff, S. Tezcan, and N. Tezcan, ed. Evliyâ Çelebi: Studies and Essays Commemorating the 4ooth Anniversary of his Birth, Istanbul, Ministry of Culture and Tourism in association with The Banks Association of Turkey, 2012, 145-53.

Gemici, N. (ed.), and Dankoff, R. (trans.). Evliya Çelebi in Medina: The Relevant Sources Sections of the Seyahatname, Leiden and Boston, Brill, 2012.

Gibb, E. J. W. A History of Ottoman Poetry, ed. E. Browne, London, Luzac \& Co., 1965.

Gök, M. and Taşkın, B. Ab-ı hayat: geçmişten günümüze İstanbul'da su ve su kültürü, Istanbul, Adell, 2010.

Göloğlu, S. "Linking, Printing, and Painting Sanctity and Protection: Representations of Mecca, Medina, and Jerusalem in Late Ottoman Illustrated Prayer Books", in A. Taşkent and N. Kançal-Ferrari, eds. The Miraj of the Prophet and Stations of His Journey, Ankara, The Independent Art Foundation with the support of the Turkish Ministry of Culture, forthcoming.

Göloğlu, S. "Touching Mecca and Medina: The Dalāil al-Khayrāt and Devotional Practices”, Khamseen: Islamic Art History Online, published 28 August 2020.

Gruber, C. The Praiseworthy One: The Prophet Muhammad in Islamic Texts and Images, Bloomington, Indiana University Press, 2019.

Gruber, C. “'Go Wherever You Wish, for Verily You are Well Protected': Seal Designs in Late Ottoman Amulet Scrolls and Prayer Books", in D. Zamani, ed. Visions of Enchantment: Occultism, Spirituality, and Visual Culture, London, Fulgur, 2019, 23-35.

Gruber, C. "In Defense and Devotion: Affective Practices in Early Modern Turco-Persian Manuscript Paintings", in K. Rizvi, ed. Affect, Emotion, and Subjectivity in Early Modern Muslim Empires: Studies in Ottoman, Safavid, and Mughal Art and Culture, Leiden, Brill, 2017, 95-123.

Gruber, C. "Between Logos (Kalima) and Light (Nūr): Representations of the Prophet Muhammad in Islamic Painting", Muqarnas 26 (2009), 1-34.

Gruber, C. "A Pious Cure-All: The Ottoman Illustrated Prayer Manual in the Lilly Library", in id., ed. The Islamic Manuscript Tradition: Ten Centuries of Book Arts in Indiana University Collections, Bloomington, Indiana University Press, 2009, 117-153.

Gülsoy, U. et al. Haremeyn: hac - mukaddese yolculuk / Hajj - Journey to Holiness, Istanbul, İstanbul Büyüksehir Belediyesi Kültür A.Ş., 2017.

Hamadeh, S. "Splash and Spectacle: The Obsession with Fountains in EighteenthCentury Istanbul", Muqarnas 19 (2002), 123-48.

Harmanşah, Ö., ed. Of Rocks and Water: Towards an Archaeology of Place, Oxford, Oxbow Books, 2014.

Hasluck, F. W. Christianity and Islam under the Sultans, Oxford, Clarendon Press, 1929. 
Hawting, G. "The Disappearance and Rediscovery of Zamzam and the 'Well of the Ka'ba”, Bulletin of the School of Oriental and African Studies 43 (1980), 44-54.

Işın, E. and Özpalabıyıklar, S. "Hoş gör yâ hû": Osmanlı kültüründe mistik semboller nesleler, Istanbul, Yapı Kredi Publications, 1999.

Ittig, A. "A Talismanic Bowl", Annales Islamologiques 18 (1982), 79-94.

Khan, Q. "Souvenirs and Gifts: Collecting Modern Hajj”, in V. Porter and L. Saif, eds. The Hajj: Collected Essays, London, The British Museum, 2013, 228-40.

Kimmelfield, I. "The Shrine of the Theotokos at the Pege", in B. Shilling and P.Stephenson, eds. Fountains and Water Culture in Byzantium, Cambridge, Cambridge University Press, 2016, 299-310.

Kissyov, S. Bachkovo Monastery, Sofia, Jusautor, 1993.

Leoni, F. "Sacred Words, Sacred Power: Qur'ānic and Pious Phrases as Sources of Healing and Protection", in F. Leoni, ed. Power and Protection: Islamic Art and the Supernatural, Oxford, Ashmolean Museum, 2016, 53-65.

Liu, L. "Glass Containers' Aura: The Gestalt of Material Milieu”, Art History 44/1 (2021), 108-120.

Matthews, H. "From the Fifteenth Century to the Present Day", in E. Kleinbauer and A. White, eds. Hagia Sophia, London, Scala, 2004, 81-104.

Mols, L. and Vrolijk, A. Western Arabia in the Leiden Collections: Traces of a Colourful Past, Leiden, Leiden Publications, 2017.

Nilsson, I. "Words, Water, and Power: Literary Fountains and Metaphors of Patronage in Eleventh- and Twelfth-Century Byzantium", in B. Shilling and P. Stephenson, eds. Fountains and Water Culture in Byzantium, Cambridge, Cambridge University Press, 2016, 265-28o.

Ousterhout, R. "Water and Healing in Constantinople: Reading the Architectural Remains", in B. Pitarakis, ed. Life is Short, Art Long: The Art of Healing in Byzantium, Istanbul, Pera Museum, 2015, 65-77.

Perk, H. Osmanlı tılsım mühürleri: Halûk Perk Koleksiyonu, Istanbul, Mat Ofset, 2010.

Perk, H. and İ. G. Paksoy, Duanın Sudaki Gizemi Şifa Taşları, Istanbul, Zeytinburnu Belediyesi and Halûk Perk Müzesi, 2011.

Porter, V. “Gifts, Souvenirs, and the Hajj”, in L. Mols and M. Buitelaar, eds. Hajj: Global Interactions Through Pilgrimage, Leiden, Sidestone Press, 2015, 95-111.

Rubin, U. "Pre-existence and Light: Aspects of the Concept of Nūr Muhammad", Israel Oriental Studies 5 (1975), 62-119.

Rubin, U. "The Ka'ba: Aspects of its Ritual Functions and Position in Pre-Islamic and Early Islamic Times", Jerusalem Studies in Arabic and Islam 8 (1986), 97-131.

Savage-Smith, E. et al. Science, Tools \& Magic. Nasser D. Khalili Collection of Islamic Art, London, Nour Foundation in association with Azimuth Editions and Oxford University Press, 1997. 
Spoer, H. H. “Arabic Magic Medicinal Bowls", Journal of the American Oriental Society 55 (1935), 237-256.

Şentürk, Ş. Cam altında yirmi bin fersah: Geleneksel halk resim sanatından camaltı resimleri, Istanbul, Yapı Kredi Publications, 1997.

Stanley, T. "From Text to Art Form in the Ottoman Hilye", in Z. Atbaş et al., eds. Filiz Çağman'a Armağan, Istanbul, Lale Yayınıcılık, 2018, 559-70.

Talbot, A.-M. "Holy Springs and Pools in Byzantine Constantinople", in P. Magdalino and N. Ergin, eds. Istanbul and Water, Leuven, Paris, and Bristol, Peeters, 2015, 161-74.

Tanman, M. B. Ekrem Hakkı Ayverdi, 1899-1984: mimarlık tarihçisi, restoratör, koleksiyoner / Architectural Historian, Restorator, Collector, Istanbul, İstanbul Araştırmalan Enstitüsü, 2014.

Taşkale, F. and Gündüz, H. Hz. Muhammed'in Özellikleri: Hat Sanatında Hilye-i Şeriffe / Characteristics of the Prophet Muhammed in Calligraphic Art, Istanbul, Kültür Yayınları, 2006.

Terzioğlu, A. Helvahane Defteri ve Topkapı Sarayında Eczacılık. Eine bisher unbekannte Arzneien im Topkapi-Schloss in Istanbul und ihre Bedeutung für die Geschichte der Pharmazie, Istanbul, Arkeoloji ve Sanat, 1992.

Teteriatnikov, N. "The Image of the Virgin Zoodochos Pege: Two Questions Concerning its Origins", in M. Vassilaki, ed. Images of the Mother of God: Perceptions of the Theotokos in Byzantium, Aldershot, Ashgate, 2005, 225-33.

Türk ve İslâm Eserleri Müzesi Rehberi, Istanbul, İstanbul Devlet Basımevi, 1939.

Walsh, R. Constantinople and the Scenery of the Seven Churches of Asia Minor Illustrated in a Series of Drawings from Nature by Thomas Allom, London and Paris, Fisher, 1838.

al-Yahsubi, Muhammad, Messenger of Allah: Ash-Shifa of Qadi Tyad, trans. A. A. Bewley, Inverness, Scotland, Madinah Press, 1991.

Zadeh, T. "An Ingestible Scripture: Qur'ānic Erasure and the Limits of 'Popular' Religion", in B. Fleming and R. Mann, eds. Material Culture and Asian Religions: Text, Image, Object, New York and London, Routledge, 2014, 97-119.

Zadeh, T. “Touching and Ingesting: Early Debates on the Material Qur'ān", Journal of the American Oriental Society 129/3 (2009), 443-66.

Zakariya, M. "The Hilye of the Prophet Muhammad", Seasons (Autumn-Winter 20032004), 13-22.

Zarcone, T. "Mevlid Kandili: La fête de la naissance du Prophète en Turquie", in N. Clayer and E. Kaynar, eds. Penser, agir et vivre dans l'Empire ottoman et en Turquie: Études reunies pour François Georgeon, Paris and Louvain, Peeters, 2013, 307-20. 